A Mechanistic Study of the Oxidative Reaction of HydrogenTerminated Si(111) Surfaces with Liquid Methanol

\author{
Noah T. Plymale, Mita Dasog, Bruce S. Brunschwig, and Nathan S. Lewis
}

J. Phys. Chem. C, Just Accepted Manuscript • DOI: 10.1021/acs.jpcc.6b11555 • Publication Date (Web): 18 Jan 2017

Downloaded from http://pubs.acs.org on January 25, 2017

Just Accepted

"Just Accepted" manuscripts have been peer-reviewed and accepted for publication. They are posted online prior to technical editing, formatting for publication and author proofing. The American Chemical Society provides "Just Accepted" as a free service to the research community to expedite the dissemination of scientific material as soon as possible after acceptance. "Just Accepted" manuscripts appear in full in PDF format accompanied by an HTML abstract. "Just Accepted" manuscripts have been fully peer reviewed, but should not be considered the official version of record. They are accessible to all readers and citable by the Digital Object Identifier (DOI®). "Just Accepted" is an optional service offered to authors. Therefore, the "Just Accepted" Web site may not include all articles that will be published in the journal. After a manuscript is technically edited and formatted, it will be removed from the "Just Accepted" Web site and published as an ASAP article. Note that technical editing may introduce minor changes to the manuscript text and/or graphics which could affect content, and all legal disclaimers and ethical guidelines that apply to the journal pertain. ACS cannot be held responsible for errors or consequences arising from the use of information contained in these "Just Accepted" manuscripts. 


\title{
A Mechanistic Study of the Oxidative Reaction of Hydrogen-Terminated Si(111) Surfaces with Liquid Methanol
}

Noah T. Plymale, ${ }^{\dagger}$ Mita Dasog, ${ }^{\dagger}$ Bruce S. Brunschwig, ${ }^{\dagger}$ and Nathan S. Lewis ${ }^{* \dagger, \ddagger \S}$

${ }^{\dagger}$ Division of Chemistry and Chemical Engineering, ${ }^{\ddagger}$ Beckman Institute, and ${ }^{\S}$ Kavli Nanoscience Institute, California Institute of Technology, Pasadena, California 91125, United States

\begin{abstract}
$\mathrm{H}-\mathrm{Si}(111)$ surfaces have been reacted with liquid methanol $\left(\mathrm{CH}_{3} \mathrm{OH}\right)$ in the absence or presence of a series of oxidants and/or illumination. Oxidant-activated methoxylation of $\mathrm{H}-$ $\mathrm{Si}(111)$ surfaces was observed in the dark after exposure to $\mathrm{CH}_{3} \mathrm{OH}$ solutions that contained the one-electron oxidants acetylferrocenium, ferrocenium, or 1,1'-dimethylferrocenium. The oxidant-activated reactivity toward $\mathrm{CH}_{3} \mathrm{OH}$ of intrinsic and n-type $\mathrm{H}-\mathrm{Si}(111)$ surfaces increased upon exposure to ambient light. The results suggest that oxidant-activated methoxylation requires that two conditions be met: (1) the position of the quasi-Fermi levels must energetically favor oxidation of the $\mathrm{H}-\mathrm{Si}(111)$ surface and (2) the position of the quasi-Fermi levels must energetically favor reduction of an oxidant in solution. Consistently, illuminated n-type H$\mathrm{Si}(111)$ surfaces underwent methoxylation under applied external bias more rapidly and at more negative potentials than p-type $\mathrm{H}-\mathrm{Si}(111)$ surfaces. The results under potentiostatic control indicate that only conditions that favor oxidation of the $\mathrm{H}-\mathrm{Si}(111)$ surface need be met, with charge balance at the surface maintained by current flow at the back of the electrode. The results are described by a mechanistic framework that analyzes the positions of the quasi-Fermi levels relative to the energy levels relevant for each system.
\end{abstract}




\section{INTRODUCTION}

The device properties of Si can be manipulated through control over the structure and chemical composition of crystalline Si surfaces. ${ }^{1-2}$ The reactivity of hydrogen-terminated $\operatorname{Si}(111)$ (H-Si(111)) surfaces toward organic nucleophiles, including alkenes, ${ }^{3-4}$ alkynes, ${ }^{5-6}$ amines, ${ }^{7-11}$ thiols and disulfides, ${ }^{12-13}$ Grignards, ${ }^{14-15}$ and alcohols, ${ }^{16-25}$ has been widely exploited to impart desirable functionality to the Si interface. These surface reactions have been used to control the interface between Si and metals, ${ }^{26-31}$ metal oxides, ${ }^{32-35}$ polymers, ${ }^{36-41}$ and redox assemblies. ${ }^{42-49}$

Many nucleophiles react with $\mathrm{H}-\mathrm{Si}(111)$ surfaces to yield unexpected products ${ }^{50-51}$ compared to analogous reactions with molecular silanes. For example, the reaction of $\mathrm{H}-\mathrm{Si}(111)$ surfaces with alcohols has no analogous molecular counterpart. ${ }^{52,18}$ The unique reactivity of H$\mathrm{Si}(111)$ surfaces with alcohols, including $\mathrm{CH}_{3} \mathrm{OH}$, has been exploited as a versatile method to impart a desired functionality to the surface via the robust $\mathrm{Si}-\mathrm{O}$ bond, without formation of a thick insulating silicon oxide layer on the surface. For example, n-Si/ $\mathrm{CH}_{3} \mathrm{OH}$ junctions have yielded high open-circuit voltages $(632-640 \mathrm{mV})$ and high device efficiencies $(12-14 \%)^{53-54}$ in regenerative photoelectrochemical cells, with the device performance correlated with low surface recombination velocities ${ }^{55-57}$ as well as the favorable band-edge positions ${ }^{58}$ of the methoxylated $\mathrm{Si}$ surface. The methoxy termination can moreover be converted to F-termination or $\mathrm{OH}$ termination, ${ }^{19,} 24$ both of which are synthetically difficult to achieve otherwise on $\operatorname{Si}(111)$ surfaces.

Small molecule silanes, such as tris(trimethylsilyl)silane (TTMSS), are generally good models for radical reactions of $\mathrm{H}-\mathrm{Si}(111)$ surfaces, because the $\mathrm{Si}-\mathrm{H}$ bond strength is comparable for both systems. ${ }^{59}$ However, in the presence of $\mathrm{CH}_{3} \mathrm{OH}$, TTMSS decomposes by Si-Si bond cleavage. ${ }^{52,60}$ Similarly, the $\mathrm{Si}-\mathrm{Si}$ bonds on H-terminated nanoporous Si surfaces, 
which typically have wider band gaps than planar $\mathrm{Si}$, cleave by thermal reaction with alcohols. ${ }^{52}$, ${ }^{61}$ In contrast, the $\mathrm{H}-\mathrm{Si}(111)$ surface primarily undergoes a substitution reaction with alcohols, resulting in $\equiv \mathrm{Si}-\mathrm{OR}$ functionality on the surface. Scanning-tunneling microscopy (STM) data have demonstrated that the $\mathrm{H}-\mathrm{Si}(111)$ surface undergoes concomitant methoxylation and microscopic etching after $30 \mathrm{~min}$ in warm $\left(65^{\circ} \mathrm{C}\right) \mathrm{CH}_{3} \mathrm{OH}$, but, as surface sites are methoxylated, the methoxylated sites become less likely to undergo etching. ${ }^{62}$

The electronic structure of crystalline Si differs significantly from that of small molecule silanes or nanoporous $\mathrm{Si}$, and is expected to play an important role in reactions that involve charge-transfer with the Si surface. The general understanding of the alkoxylation mechanism has been focused primarily on a qualitative discussion that implicates both the narrow band gap and the much larger number of electronic states of bulk Si than of analogous molecular silanes. The previously proposed mechanisms and net chemical reactions of the methoxylation of $\mathrm{H}-$ Si(111) surfaces (reproduced in Scheme $1^{21}$ and Scheme $2^{18}$ ) provide a description of the chemical transformations that take place during surface alkoxylation, but the kinetic formalism that governs the oxidative methoxylation of $\mathrm{H}-\mathrm{Si}(111)$ surfaces is not clearly defined. Elucidating the mechanistic framework that governs the reaction of $\mathrm{H}-\mathrm{Si}(111)$ surfaces with $\mathrm{CH}_{3} \mathrm{OH}$ in the presence of a series of oxidants thus offers an opportunity to determine the role that the Si electronic structure plays in oxidative reactions at Si surfaces.

\section{Scheme 1. Methoxylation of H-Si(111) Surfaces in the Absence of a Molecular Oxidant. ${ }^{21}$}

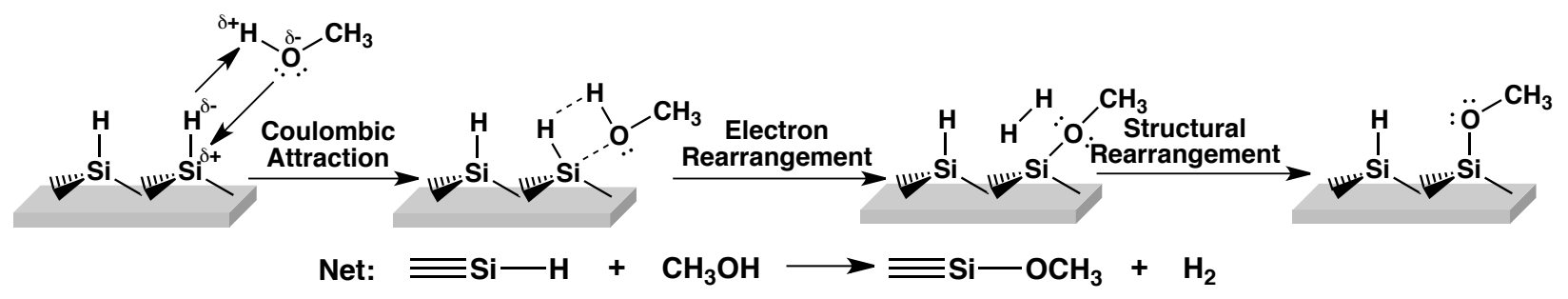


Scheme 2. Oxidant-Activated Methoxylation of H-Si(111). ${ }^{18}$

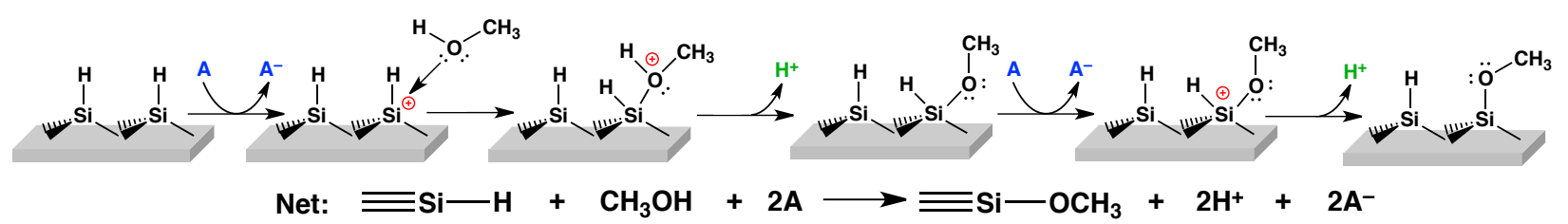

Herein we characterize the reaction of $\mathrm{H}-\mathrm{Si}(111)$ surfaces with $\mathrm{CH}_{3} \mathrm{OH}$ in the absence or presence of an oxidant and in the absence or presence of visible-light illumination. We have elucidated the dependence of the methoxylation reaction on the formal potential of the oxidant. Additionally, we have delineated the roles of the electronic surface states and bulk Si band structure in the electron-transfer processes that are involved in the methoxylation reaction. A general mechanism by which the reaction of $\mathrm{H}-\mathrm{Si}(111)$ surfaces with $\mathrm{CH}_{3} \mathrm{OH}$ takes place under the conditions studied is proposed in the context of a charge transfer kinetics framework at the semiconductor interface.

\section{EXPERIMENAL}

II.A. Materials and Methods. Water $(\geq 18.2 \mathrm{M} \Omega \mathrm{cm}$ resistivity) was obtained from a Barnstead E-Pure system. Aqueous ammonium fluoride $\left(\mathrm{NH}_{4} \mathrm{~F}(\mathrm{aq}), 40 \%\right.$ semiconductor grade, Transene Co. Inc., Danvers MA) was deaerated by bubbling with Ar(g) (99.999\%, Air Liquide) for $\geq 1 \mathrm{~h}$ prior to use. Methanol $\left(\mathrm{CH}_{3} \mathrm{OH}\right.$, anhydrous, $\geq 99.8 \%$, Sigma-Aldrich) was used as received. Float-zone-grown, phosphorus-doped n-Si(111) "intrinsic" wafers (University Wafer, Boston, MA) were double-side polished, $525 \pm 15 \mu \mathrm{m}$ thick, oriented within $0.5^{\circ}$ of the (111) crystal plane, and had a resistivity of $2.0 \mathrm{k} \Omega \mathrm{cm}$. Czochralski-grown, phosphorus-doped n-Si(111) wafers (Virginia Semiconductor, Fredericksburg, VA) were double-side polished, $381 \pm 25 \mu \mathrm{m}$ thick, oriented within $0.1^{\circ}$ of the (111) crystal plane, and had a resistivity of $1.0 \Omega \mathrm{cm}$. Czochralski-grown, boron-doped p-Si(111) wafers (Addison Engineering, San Jose, CA) were 
double-side polished, $300 \pm 25 \mu \mathrm{m}$ thick, oriented within $0.5^{\circ}$ of the (111) crystal plane, and had a resistivity of $0.40 \Omega \mathrm{cm}$.

The dopant densities $\left(N_{\mathrm{d}}\right)$ were determined from the resistivities for each Si substrate. ${ }^{63}$ For intrinsic $\operatorname{Si}(111), N_{\mathrm{d}}=2.2 \times 10^{12} \mathrm{~cm}^{-3}$; for n-type $\operatorname{Si}(111), N_{\mathrm{d}}=4.9 \times 10^{15} \mathrm{~cm}^{-3}$; and for $\mathrm{p}$ type $\operatorname{Si}(111), N_{\mathrm{d}}=4.2 \times 10^{16} \mathrm{~cm}^{-3}$. The positions of the n-type and p-type $\mathrm{Si}(111)$ bulk Fermi levels ( $\mathbf{E}_{\mathrm{F}, \mathrm{n}, \mathrm{b}}$ and $\mathbf{E}_{\mathrm{F}, \mathrm{p}, \mathrm{b}}$, respectively) were determined using eq 1 and eq 2, respectively, for each of the dopant concentrations used.

$$
\begin{aligned}
& \mathbf{E}_{\mathrm{F}, \mathrm{n}, \mathrm{b}}=\mathbf{E}_{\mathrm{cb}}+k_{\mathrm{B}} T \ln \left(\frac{N_{\mathrm{d}}}{N_{\mathrm{C}}}\right) \\
& \mathbf{E}_{\mathrm{F}, \mathrm{p}, \mathrm{b}}=\mathbf{E}_{\mathrm{vb}}-k_{\mathrm{B}} T \ln \left(\frac{N_{\mathrm{d}}}{N_{\mathrm{v}}}\right)
\end{aligned}
$$

$\mathbf{E}_{\mathrm{cb}}$ and $\mathbf{E}_{\mathrm{vb}}$ are the energy positions of the Si conduction band minimum $\left(-4.05 \mathrm{eV}\right.$ vs $\left.\mathbf{E}_{\mathrm{Vac}}\right)$ and Si valence band maximum $\left(-5.17 \mathrm{eV}\right.$ vs $\left.\mathbf{E}_{\mathrm{Vac}}\right),{ }^{64}$ respectively, $k_{\mathrm{B}}$ is the Boltzmann constant, $T$ is the temperature in Kelvin $(296 \mathrm{~K}), q$ is the absolute value of the elementary charge, $N_{\mathrm{C}}$ is the effective density of states of the Si conduction band $\left(2.8 \times 10^{19} \mathrm{~cm}^{-3}\right)$ and $N_{\mathrm{V}}$ is the effective density of states of the Si valence band $\left(1.0 \times 10^{19} \mathrm{~cm}^{-3}\right)$. The bulk Fermi level of intrinsic $\operatorname{Si}(111)\left(\mathbf{E}_{\mathrm{F}, \mathrm{i}, \mathrm{b}}\right)$, which was lightly n-type, was determined using eq 1.

II.A.1. Preparation and Purification of the Oxidants. 1,1'-dimethylferrocenium $\left(\mathrm{Me}_{2} \mathrm{Cp}_{2} \mathrm{Fe}^{+} \mathrm{BF}_{4}^{-}, \quad\right.$ bis(methylcyclopentadienly)iron(III) tetrafluoroborate), octamethylferrocenium ( $\mathrm{Me}_{8} \mathrm{Cp}_{2} \mathrm{Fe}^{+} \mathrm{BF}_{4}^{-}$, bis(tetramethylcyclopentadienyl)iron(III) tetrafluoroborate), and decamethylferrocenium $\left(\mathrm{Cp}_{2}{ }_{2} \mathrm{Fe}^{+} \mathrm{BF}_{4}^{-}\right.$, bis(pentamethylcyclopentadienyl)iron(III) tetrafluoroborate) were prepared by chemical oxidation of the neutral metallocenes ${ }^{65-66} 1,1^{\prime}$-dimethylferrocene $\left(\mathrm{Me}_{2} \mathrm{Cp}_{2} \mathrm{Fe}\right.$, bis(methylcyclopentadienyl)iron(II), 95\%, Sigma-Aldrich), octamethylferrocene $\left(\mathrm{Me}_{8} \mathrm{Cp}_{2} \mathrm{Fe}, \quad\right.$ bis(tetramethylcyclopentadienyl)iron(II), $\quad 98 \%, \quad$ Strem $\quad$ Chemical), and 
decamethylferrocene (Cp* ${ }_{2} \mathrm{Fe}$, bis(pentamethylcyclopentadienyl)iron(II), 99\%, Strem Chemical), respectively. Ferrocenium $\left(\mathrm{Cp}_{2} \mathrm{Fe}^{+} \mathrm{BF}_{4}^{-}\right.$, bis(cyclopentadienyl)iron(III) tetrafluoroborate, technical grade, Sigma-Aldrich) $\mathrm{Me}_{2} \mathrm{Cp}_{2} \mathrm{Fe}^{+} \mathrm{BF}_{4}^{-}, \mathrm{Me}_{8} \mathrm{Cp}_{2} \mathrm{Fe}^{+} \mathrm{BF}_{4}^{-}$, and $\mathrm{Cp}_{2}{ }_{2} \mathrm{Fe}^{+} \mathrm{BF}_{4}^{-}$were purified by recrystallization from diethyl ether (inhibitor-free, $\geq 99.9 \%$ Sigma-Aldrich) and $\mathrm{CH}_{3} \mathrm{CN}$ (anhydrous, $\geq 99.8 \%$ Sigma-Aldrich). Methyl viologen $\left(\mathrm{MV}^{2+}\left(\mathrm{Cl}^{-}\right)_{2}, 1,1^{\prime}\right.$-dimethyl-4,4'bipyridinium dichloride hydrate, $98 \%$, Sigma-Aldrich) and cobaltocenium $\left(\mathrm{Cp}_{2} \mathrm{Co}^{+} \mathrm{PF}_{6}^{-}\right.$, bis(cyclopentadienyl)cobalt(III) hexafluorophosphate, 98\%, Sigma-Aldrich) were recrystallized from ethanol (anhydrous, $\geq 99.5 \%$ Sigma-Aldrich) prior to use. Acetylferrocenium $\left(\left(\mathrm{CpCOCH}_{3}\right) \mathrm{CpFe}^{+}, \quad\right.$ (acetylcyclopentadienyl)cyclopentadienyliron(III)) was generated in $\mathrm{CH}_{3} \mathrm{OH}$ containing $1.0 \mathrm{M} \mathrm{\textrm {LiClO } _ { 4 }}$ (battery grade, Sigma-Aldrich) from acetylferrocene $\left(\left(\mathrm{CpCOCH}_{3}\right) \mathrm{CpFe}\right.$, acetylcyclopentadienyl)cyclopentadienyliron(II), Sigma-Aldrich, purified by sublimation) by controlled-potential electrolysis at a Pt mesh working electrode with a Pt mesh counter electrode located in a compartment separated from the working electrode by a Vycor frit. ${ }^{66}$ The electrolysis was performed at $+0.5 \mathrm{~V}$ vs a Pt pseudo-reference electrode, and sufficient current was passed to generate $1.0 \mathrm{mM}\left(\mathrm{CpCOCH}_{3}\right) \mathrm{CpFe}^{+}$from $10 \mathrm{mM}\left(\mathrm{CpCOCH}_{3}\right) \mathrm{CpFe}$. The $\left(\mathrm{CpCOCH}_{3}\right) \mathrm{CpFe}^{+}$was used within 1 min of its generation.

II.A.2. Preparation of $H$-Si(111) Surfaces. Si wafers were scored and broken to the desired size using a diamond- or carbide-tipped scribe. The Si surfaces were rinsed sequentially with water, methanol $(\geq 99.8 \%, \mathrm{BDH})$, acetone $(\geq 99.5 \%, \mathrm{BDH})$, methanol, and water. The samples were oxidized in a piranha solution (1:3 v/v of $30 \% \mathrm{H}_{2} \mathrm{O}_{2}(\mathrm{aq})\left(\right.$ EMD): $18 \mathrm{M} \mathrm{H}_{2} \mathrm{SO}_{4}(\mathrm{aq})$ (EMD)) for $10-15 \mathrm{~min}$ at $95 \pm 5^{\circ} \mathrm{C}$. The wafers were removed, rinsed with copious amounts of water, and immersed in buffered hydrofluoric acid(aq) (BHF, semiconductor grade, Transene Co. Inc.) for $18 \mathrm{~s}$. The BHF solution was drained and the wafers were rinsed with $\mathrm{H}_{2} \mathrm{O}$. Anisotropic 
etching was then performed in an $\mathrm{Ar}(\mathrm{g})$-purged solution of $40 \% \mathrm{NH}_{4} \mathrm{~F}(\mathrm{aq})$ for $5.5 \mathrm{~min}$ for wafers having a $0.5^{\circ}$ miscut angle, and for $9.0 \mathrm{~min}$ for wafers having a $0.1^{\circ}$ miscut angle. ${ }^{67}$ The wafers were removed, rinsed with $\mathrm{H}_{2} \mathrm{O}$, and dried under a stream of $\operatorname{Ar}(\mathrm{g})$.

II.A.3. Methoxylation of H-Si(111) Surfaces. The H-Si(111) wafers were transferred to a $\mathrm{N}_{2}(\mathrm{~g})$-purged glovebox $\left(<10\right.$ ppm $\left.\mathrm{O}_{2}(\mathrm{~g})\right)$ and immersed in either neat $\mathrm{CH}_{3} \mathrm{OH}$ or in a solution of $\mathrm{CH}_{3} \mathrm{OH}$ that contained $1.0 \mathrm{mM}$ of $\left(\mathrm{CpCOCH}_{3}\right) \mathrm{CpFe}^{+}, \mathrm{Cp}_{2} \mathrm{Fe}^{+} \mathrm{BF}_{4}^{-}, \mathrm{Me}_{2} \mathrm{Cp}_{2} \mathrm{Fe}^{+} \mathrm{BF}_{4}^{-}$, $\mathrm{Me}_{8} \mathrm{Cp}_{2} \mathrm{Fe}^{+} \mathrm{BF}_{4}^{-}, \mathrm{Cp}_{2}{ }_{2} \mathrm{Fe}^{+} \mathrm{BF}_{4}^{-}, \mathrm{MV}^{2+} 2 \mathrm{Cl}^{-}$, or $\mathrm{Cp}_{2} \mathrm{Co}^{+} \mathrm{PF}_{6}^{-}$. Reactions in the dark were performed in test tubes wrapped in black vinyl electrical tape with the top covered in Al foil, whereas reactions in the light were performed under ambient illumination. Upon completion of the reaction, the wafers were removed from the $\mathrm{CH}_{3} \mathrm{OH}$ solution and rinsed sequentially with $\mathrm{CH}_{3} \mathrm{OH}$ and tetrahydrofuran (THF, anhydrous, $\geq 99.9 \%$, Sigma-Aldrich). The THF was allowed to evaporate and the samples were removed from the glovebox. Prior to analysis, the wafers were rinsed briefly with $\mathrm{H}_{2} \mathrm{O}$ and dried under a stream of $\mathrm{Ar}(\mathrm{g})$.

II.A.4. Potentiostatic Methoxylation of H-Si(111). Si samples were cleaned using a piranha solution for $10 \mathrm{~min}$ at $95 \pm 5^{\circ} \mathrm{C}$ and etched in $\mathrm{BHF}$ for $18 \mathrm{~s}$ prior to electrode fabrication. Ohmic contacts to the back of $\mathrm{n}-\mathrm{Si}(111)(1.0 \Omega \mathrm{cm})$ electrodes were made by using a diamondtipped scribe to apply Ga-In eutectic ( $78 \% \mathrm{Ga}, 22 \%$ In by weight). Ohmic contacts to the back of p-Si(111) $(0.40 \Omega \mathrm{cm})$ electrodes were made by electron-beam evaporation (Denton Vacuum) of $100 \mathrm{~nm}$ of $\mathrm{Al}$ to the rear face of the electrode, followed by a $30 \mathrm{~min}$ anneal under forming gas $(5 \%$ $\mathrm{H}_{2}(\mathrm{~g})$ in $\left.\mathrm{N}_{2}(\mathrm{~g})\right)$ at $450{ }^{\circ} \mathrm{C} .{ }^{6}$ Using high-purity conductive $\mathrm{Ag}$ paint (SPI supplies, West Chester, PA), the Si working electrodes were adhered to a coil of tinned $\mathrm{Cu}$ wire that had been threaded through 1/4" outer-diameter Pyrex tubing. Loctite 9460 epoxy was used to insulate the rear face of the electrode from the electrolyte as well as to immobilize the Si wafer such that the electrode 
face was perpendicular to the length of the tubing. ${ }^{68}$ The electrode areas $\left(0.2-0.4 \mathrm{~cm}^{2}\right)$ were measured by analysis of scanned images of the electrodes using ImageJ software.

Immediately prior to performing the electrochemical experiments, the electrodes were immersed in BHF for $18 \mathrm{~s}$, rinsed with water, and dried thoroughly. The electrodes were then immersed in $40 \% \mathrm{NH}_{4} \mathrm{~F}(\mathrm{aq})$, with wafers having a $0.5^{\circ}$ miscut angle immersed for $5.5 \mathrm{~min}$ whereas wafers that had a $0.1^{\circ}$ miscut angle were immersed for $9.0 \mathrm{~min}$. The electrodes were rinsed with water and dried thoroughly prior to performing electrochemical measurements.

Electrochemical measurements were performed in a four-port, cylindrical, flat-bottomed, borosilicate glass cell that contained $\mathrm{CH}_{3} \mathrm{OH}$ with $1.0 \mathrm{M} \mathrm{LiClO}_{4}$. Electrochemical measurements were collected using a Solartron 1286 model potentiostat operated by CorrWare software v. 3.2c. Current density vs potential $(J-E)$ measurements were collected using a 3-electrode setup with a Si working electrode, a saturated calomel reference electrode (SCE, CH instruments, Inc., Austin TX), and a Pt mesh counter electrode. $J-E$ data were collected by sweeping the potential from negative to positive using a scan rate of $50 \mathrm{mV} \mathrm{s}^{-1}$ and a sampling rate of $1 \mathrm{mV}$ per data point, with active stirring of the electrolyte. Measurements were performed in the dark as well as under

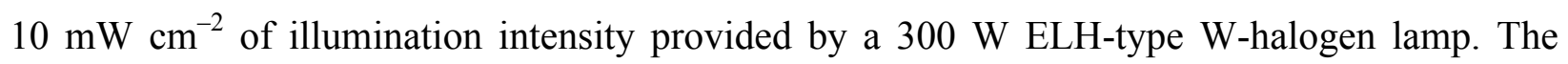
illumination intensity was determined by use of a calibrated Si photodiode (Thor Laboratories, Newton, NJ).

II.A.5. Determination of the Formal Potentials of the Oxidants. The formal potentials of the oxidant species $\left(1.0 \mathrm{mM}\right.$ in $\left.\mathrm{CH}_{3} \mathrm{OH}\right)$ were determined by cyclic voltammetry vs a $\mathrm{Cp}_{2} \mathrm{Fe}^{+/ 0}$ internal reference using $\mathrm{Pt}$ wire working and reference electrodes with a $\mathrm{Pt}$ mesh counter electrode. The formal potential of the $\mathrm{Cp}_{2} \mathrm{Fe}^{+/ 0}$ couple was measured vs a SCE reference $\left(E^{\circ}\left(\mathrm{Cp}_{2} \mathrm{Fe}^{+/ 0}\right)=0.325 \mathrm{~V}\right.$ vs $\left.\mathrm{SCE}\right)$, and this potential was used to convert from $\mathrm{V}$ vs $\mathrm{Cp}_{2} \mathrm{Fe}^{+/ 0}$ to 
$\mathrm{V}$ vs SCE. The supporting electrolyte was $1.0 \mathrm{M} \mathrm{LiClO}_{4}$ for $\left(\mathrm{CpCOCH}_{3}\right) \mathrm{CpFe}^{+/ 0}, \mathrm{Cp}_{2} \mathrm{Fe}^{+/ 0}$, $\mathrm{Me}_{2} \mathrm{Cp}_{2} \mathrm{Fe}^{+/ 0}, \mathrm{Me}_{8} \mathrm{Cp}_{2} \mathrm{Fe}^{+/ 0}, \mathrm{Cp}_{2}{ }_{2} \mathrm{Fe}^{+/ 0}$, and $\mathrm{Cp}_{2} \mathrm{Co}^{+/ 0}$ and was $0.1 \mathrm{M}$ tetrabutylammonium hexafluorophosphate $\left(\mathrm{TBAPF}_{6}\right.$, Sigma-Aldrich) for $\mathrm{MV}^{2+/+}$. Nernstian solution potentials $\left(E\left(\mathrm{~A} / \mathrm{A}^{-}\right)\right)$and formal reduction potentials $\left(E^{\circ}\left(\mathrm{A} / \mathrm{A}^{-}\right)\right)$were converted to absolute electron energies using a value of $-4.44 \mathrm{eV}$ vs $\mathbf{E}_{\mathrm{vac}}$ for the absolute electrochemical potential of the standard hydrogen electrode (SHE) at $25{ }^{\circ} \mathrm{C} .{ }^{69-70}$ Because the redox potential of SCE is $+0.24 \mathrm{~V}$ vs $\mathrm{SHE},{ }^{71} E\left(\mathrm{~A} / \mathrm{A}^{-}\right)$and $E^{\circ},\left(\mathrm{A} / \mathrm{A}^{-}\right)$in $\mathrm{V}$ vs $\mathrm{SCE}$ can be readily converted to solution energies $\left(\mathbf{E}\left(\mathrm{A} / \mathrm{A}^{-}\right)\right)$and formal reduction energies $\left(\mathbf{E}^{\circ}\left(\mathrm{A} / \mathrm{A}^{-}\right)\right)$in $\mathrm{eV}$ vs $\mathbf{E}_{\mathrm{Vac}}$ using eqs 3 and 4 , respectively.

$$
\begin{gathered}
\mathbf{E}\left(\mathrm{A} / \mathrm{A}^{-}\right) \text {vs } \mathbf{E}_{\mathrm{Vac}}=-\left(E\left(\mathrm{~A} / \mathrm{A}^{-}\right) \text {vs } \mathrm{SCE}\right)-4.68 \mathrm{eV} \\
\mathbf{E}^{\circ \prime}\left(\mathrm{A} / \mathrm{A}^{-}\right) \text {vs } \mathbf{E}_{\mathrm{Vac}}=-\left(E^{\circ \prime}\left(\mathrm{A} / \mathrm{A}^{-}\right) \text {vs } \mathrm{SCE}\right)-4.68 \mathrm{eV}
\end{gathered}
$$

II.B. Instrumentation. II.B.1. Transmission Infrared Spectroscopy. Transmission infrared spectroscopy (TIRS) was performed using a Thermo Scientific Nicolet 6700 optical spectrometer equipped with an electronically temperature-controlled EverGlo mid-IR source, a $\mathrm{KBr}$ beamsplitter, a deuterated L-alanine-doped triglycine sulfate (DLaTGS) detector, and a $\mathrm{N}_{2}(\mathrm{~g})$ purge. ${ }^{67-68}$ The samples, cut to $\sim 1.3 \times 3.2 \mathrm{~cm}$, were mounted using a custom attachment such that the angle between the path of the beam and the surface normal was $74^{\circ}$ (Brewster's angle for $\mathrm{Si}$ ). The reported spectra are averages of 1500 consecutive scans collected at $4 \mathrm{~cm}^{-1}$ resolution. Spectra were referenced to a spectrum of a Si wafer that was H-terminated or that was covered with silicon oxide $\left(\mathrm{SiO}_{\mathrm{x}}\right)$, with reference spectra collected separately for each sample. Data were collected and processed using OMNIC software v. 9.2.41. The baseline was flattened and residual water peaks were subtracted to produce the reported spectral data. 
II.B.2. X-ray Photoelectron Spectroscopy. X-ray photoelectron spectroscopic (XPS) data were collected using a Kratos AXIS Ultra spectrometer equipped with a monochromatic Al Ka X-ray source at $1486.7 \mathrm{eV}$, a hybrid electrostatic and magnetic lens system, and a delay-line detector. ${ }^{67-68}$ Photoelectrons from a $700 \mu \mathrm{m} \times 300 \mu \mathrm{m}$ area were ejected at $90^{\circ}$ with respect to the sample surface. Survey and high-resolution spectra were collected with an analyzer pass energy of $80 \mathrm{eV}$ and $10 \mathrm{eV}$, respectively. The chamber base pressure was $\sim 8 \times 10^{-10}$ Torr. Calibration of the energy scale and work function was performed using clean $\mathrm{Au}, \mathrm{Ag}$, and $\mathrm{Cu}$ samples. The data were collected using Vision Manager software v. 2.2.10 revision 5.

II.C. Analysis of TIRS and XPS Data. II.C.1. Calculation of the Fractional Methoxy Monolayer Coverage from TIRS Data. The fractional monolayer (ML) coverage of H-Si(111) sites remaining after reaction in $\mathrm{CH}_{3} \mathrm{OH}\left(\theta_{\mathrm{Si}-\mathrm{H}}\right)$ was determined using eq 5

$$
\theta_{\mathrm{Si}-\mathrm{H}}=\frac{A_{v(\mathrm{Si}-\mathrm{H}), f}}{A_{v(\mathrm{Si}-\mathrm{H}), i}}
$$

where $A_{v(\mathrm{Si}-\mathrm{H}), f}$ and $A_{v(\mathrm{Si}-\mathrm{H}), i}$ are the final and initial area, respectively, under the $\mathrm{Si}-\mathrm{H}$ stretching peak. Assuming that all atop sites are terminated by $\mathrm{Si}-\mathrm{H}$ or $\mathrm{Si}-\mathrm{OCH}_{3}$ groups, the fractional ML coverage of $\mathrm{CH}_{3} \mathrm{O}-\mathrm{Si}(111)$ sites $\left(\theta_{\mathrm{Si}-\mathrm{OCH}_{3}}\right)$ was determined using eq 6

$$
\theta_{\mathrm{Si}-\mathrm{OCH}_{3}}=1-\theta_{\mathrm{Si}-\mathrm{H}}
$$

II.C.2. Calculation of the Fractional Methoxy Monolayer Coverage from XPS Data. High-resolution C 1s and Si 2p XPS data were analyzed using CasaXPS v. 2.3.16. C 1s spectra were fitted using a Voigt GL(30) line function, which consisted of 70\% Gaussian and 30\% Lorentzian character. Bulk Si $2 p$ data were fitted using a line function of the form $\operatorname{LA}(a, b, n)$, where $a$ and $b$ define the asymmetry of the line shape and $n$ defines the Gaussian width. LA(1.2, 
$1.4,200)$ was used in this work. Contributions from $\mathrm{SiO}_{\mathrm{x}}$ were fitted using the GL(30) line shape. Spectra were analyzed using a linear background.

A substrate-overlayer model was used to determine the thickness of the methoxy overlayer, $d_{\mathrm{Si}-\mathrm{OCH}_{3}}$, by XPS:

$$
\left(\frac{I_{\mathrm{C}-\mathrm{O}}}{I_{\mathrm{Si}}}\right)\left(\frac{S F_{\mathrm{Si}}}{S F_{\mathrm{C}-\mathrm{O}}}\right)\left(\frac{\rho_{\mathrm{Si}}}{\rho_{\mathrm{C}-\mathrm{O}}}\right)=\left(\frac{1-e^{-\frac{d_{\mathrm{Si}-\mathrm{OCH}}}{\lambda_{\mathrm{C}-\mathrm{O}} \sin \varphi}}}{e^{-\frac{d_{\mathrm{Si}-\mathrm{OCH}}}{\lambda_{\mathrm{Si}} \mathrm{in} \varphi}}}\right)
$$

$I_{\mathrm{C}-\mathrm{O}}$ and $I_{\mathrm{Si}}$ are the areas under the photoemission peaks arising from $\mathrm{C}$ bound to $\mathrm{O}$ and from bulk $\mathrm{Si}$, respectively, $S F_{\mathrm{C}-\mathrm{O}}$ and $S F_{\mathrm{Si}}$ are the sensitivity factors for the C 1s (0.278) and $\mathrm{Si} 2 \mathrm{p}$ (0.328) photoemission signals, respectively, $\rho_{\mathrm{C}-\mathrm{O}}$ and $\rho_{\mathrm{Si}}$ are the density of the hydrocarbon overlayer $\left(3.0 \mathrm{~g} \mathrm{~cm}^{-3}\right)$ and $\mathrm{Si}\left(2.3 \mathrm{~g} \mathrm{~cm}^{-3}\right)$, respectively, $\lambda_{\mathrm{C}-\mathrm{O}}$ and $\lambda_{\mathrm{Si}}$ are the attenuation lengths of C 1s photoelectrons $(3.6 \mathrm{~nm})$ and $\mathrm{Si} 2 \mathrm{p}$ photoelectrons $(4.0 \mathrm{~nm})$, respectively, moving through a hydrocarbon overlayer, and $\varphi$ is the angle between the photoelectron emission vector and the sample surface normal $\left(90^{\circ}\right.$ for this work). The thickness $d_{\mathrm{Si}_{-} \mathrm{OCH}_{3}}$ was determined using an iterative calculation process, and $\theta_{\mathrm{Si}-\mathrm{OCH}_{3}}$ was calculated by dividing the calculated $d_{\mathrm{Si}-\mathrm{OCH}_{3}}$ by the estimated thickness of $1 \mathrm{ML}$ of methoxy groups $(0.20 \mathrm{~nm})$.

\section{RESULTS}

III.A. Reaction of $\mathrm{H}-\mathrm{Si}(111)$ with $\mathrm{CH}_{3} \mathrm{OH}$ Solutions in the Dark. Figure 1 presents time dependence for the dark reaction of $\mathrm{H}-\mathrm{Si}(111)$ surfaces with $\mathrm{CH}_{3} \mathrm{OH}$ in the absence or presence of $\mathrm{Cp}_{2} \mathrm{Fe}^{+}$. The reaction of $\mathrm{H}-\mathrm{Si}(111)$ with $\mathrm{CH}_{3} \mathrm{OH}$ proceeded slowly in the absence of electron acceptors in solution, but increased substantially upon addition of $\mathrm{Cp}_{2} \mathrm{Fe}^{+}$. This observation agrees with previous results that describe increased reaction rates for the methoxylation of $\mathrm{H}-\mathrm{Si}(111)$ in $\mathrm{CH}_{3} \mathrm{OH}$ solutions that contained $\mathrm{Cp}_{2} \mathrm{Fe}^{+}$or $\mathrm{Me}_{2} \mathrm{Cp}_{2} \mathrm{Fe}^{+} \cdot 18,21,72-73$ 
After 5 min of reaction, a difference in the area of the $\mathrm{Si}-\mathrm{H}$ stretching peak, $v(\mathrm{Si}-\mathrm{H})$, was observed in the presence of $\mathrm{Cp}_{2} \mathrm{Fe}^{+}$relative to the reaction in the absence of the deliberately added oxidant. A greater difference was observed for a 15 min reaction time, but measurable subsurface silicon oxide $\left(\mathrm{SiO}_{\mathrm{x}}\right)$ was consistently observed after $15 \mathrm{~min}$ in the presence of $\mathrm{Cp}_{2} \mathrm{Fe}^{+}$. Hence, a 5 min reaction time was chosen as a standard point of comparison in this work.

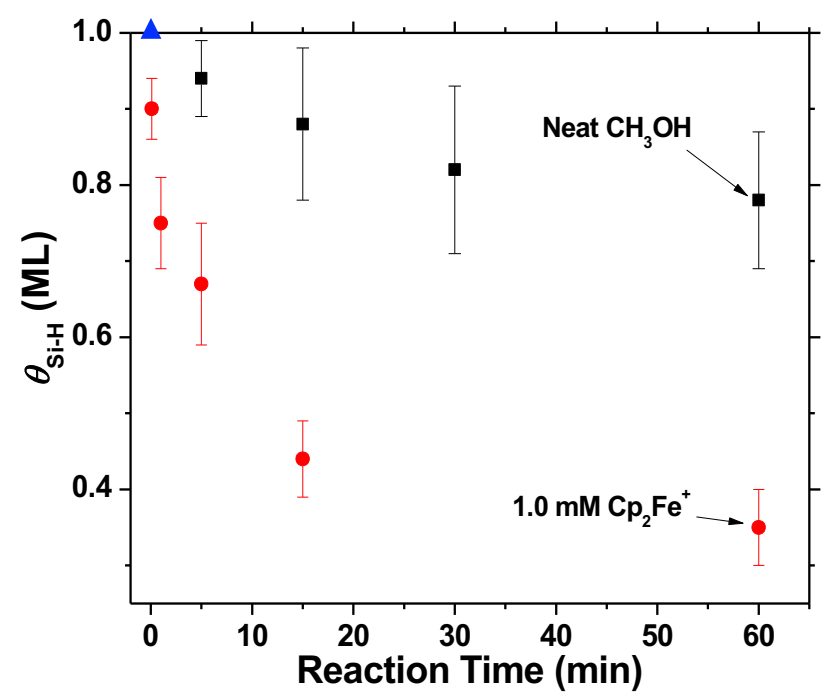

Figure 1. Time dependence of the reaction of $\mathrm{H}-\mathrm{Si}(111)$ with neat $\mathrm{CH}_{3} \mathrm{OH}$ (black squares) and $\mathrm{CH}_{3} \mathrm{OH}$ containing $1.0 \mathrm{mM} \mathrm{Cp}{ }_{2} \mathrm{Fe}^{+}$(red circles) in the dark. $\theta_{\mathrm{Si}-\mathrm{H}}$ was determined from TIRS measurements using eq 5. The blue triangle represents the assumed 1.0 ML Si-H on surfaces that have not been reacted with $\mathrm{CH}_{3} \mathrm{OH}$.

The reaction of $\mathrm{H}-\mathrm{Si}(111)$ surfaces with liquid $\mathrm{CH}_{3} \mathrm{OH}$ was performed for $5 \mathrm{~min}$ in solutions that contaianed $1.0 \mathrm{mM}$ of the oxidants indicated in Figure 2 as well as in neat $\mathrm{CH}_{3} \mathrm{OH}$. The experimentally determined formal potentials, $E^{\circ}\left(\mathrm{A} / \mathrm{A}^{-}\right)$, for each oxidant are indicated relative to the energy positions of the $\mathrm{Si}$ valence-band maximum, the $\mathrm{Si}$ conduction-band minimum, and the Fermi levels of the planar Si samples used in this work. ${ }^{64}$ The formal potentials of the oxidants span the range from below the valence-band maximum to above the 
conduction-band minimum. Note that because only the oxidized species was added to the $\mathrm{CH}_{3} \mathrm{OH}$ reaction solutions for all reagents except $\left(\mathrm{CpCOCH}_{3}\right) \mathrm{CpFe}^{+}$, the Nernstian solution potentials were thus shifted positive of the measured formal potentals.

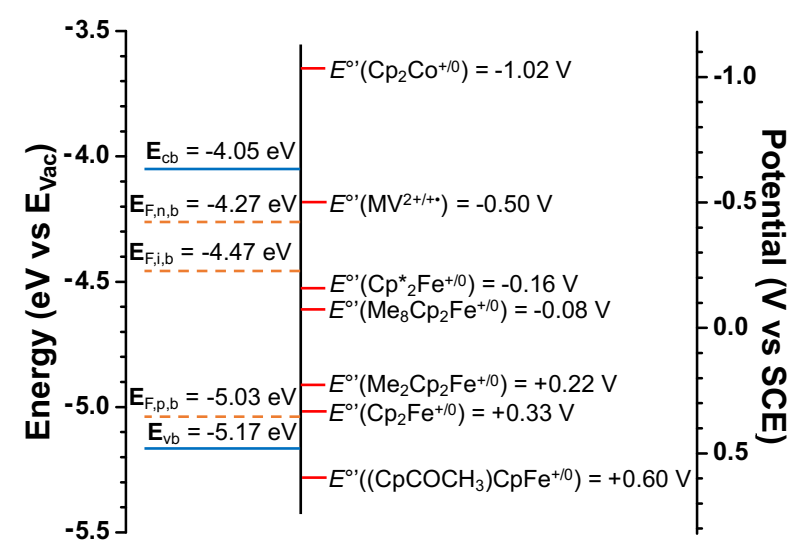

Figure 2. Energy diagram showing the relative energy positions vs the vacuum level $\left(\mathbf{E}_{\mathrm{Vac}}\right)$ of the Si valence-band maximum $\left(\mathbf{E}_{\mathrm{vb}}\right),{ }^{64} \mathrm{Si}$ conduction-band minimum $\left(\mathbf{E}_{\mathrm{cb}}\right),{ }^{64}$ and the calculated bulk Fermi levels (eq 1 and eq 2 ) of the intrinsic $\operatorname{Si}(111)\left(\mathbf{E}_{\mathrm{F}, \mathrm{i}, \mathrm{b}}\right), \mathrm{n}$-type $\operatorname{Si}(111)\left(\mathbf{E}_{\mathrm{F}, \mathrm{n}, \mathrm{b}}\right)$, and ptype $\operatorname{Si}(111)\left(\mathbf{E}_{\mathrm{F}, \mathrm{p}, \mathrm{b}}\right)$ used in this work. The measured formal potentials $\left(E^{\circ}\right)$ vs $\mathrm{SCE}$ of each oxidant are indicated relative to the Si band positions, where eq 4 was used to convert potentials in $\mathrm{V}$ vs SCE to energies in eV vs $\mathbf{E}_{\mathrm{Vac} .}$.

Figure 3 shows TIRS data for $\mathrm{H}-\mathrm{Si}(111)$ surfaces after 5 min of exposure to $\mathrm{CH}_{3} \mathrm{OH}$ in the presence or absence of the indicated oxidants. The peak positions, shifts, and assignments have been described previously. ${ }^{21}$ The $v(\mathrm{Si}-\mathrm{H})$ peak (Figure 3a) broadened and reduced in intensity with increasing formal potential of the oxidant. For the reactions using $\left(\mathrm{CpCOCH}_{3}\right) \mathrm{CpFe}^{+}, \mathrm{Cp}_{2} \mathrm{Fe}^{+}$, and $\mathrm{Me}_{2} \mathrm{Cp}_{2} \mathrm{Fe}^{+}$as oxidants, the $v(\mathrm{Si}-\mathrm{H})$ peak was significantly less intense and broader than for reactions performed using weaker oxidants, indicating increased loss of $\mathrm{Si}-\mathrm{H}$ on the surface. The increased activity of these three oxidants was additionally 
supported by large relative areas observed under the $\mathrm{C}-\mathrm{H}$ stretching, $v(\mathrm{C}-\mathrm{H})_{\mathrm{CH}_{3}}$, peaks (Figure $3 \mathrm{~b}$ ), as well as the large areas observed under the $\mathrm{C}-\mathrm{H}$ symmetric bending, $\delta_{\mathrm{s}}(\mathrm{C}-\mathrm{H})_{\mathrm{CH}_{3}}$, peak in addition to the peak that is composed of an $\mathrm{O}-\mathrm{C}$ stretching mode coupled with a $-\mathrm{CH}_{3}$ rocking mode, $v(\mathrm{O}-\mathrm{C})+\rho\left(\mathrm{CH}_{3}\right)$ (Figure 3c). A broad and low-intensity shoulder on the low energy side of the $v(\mathrm{O}-\mathrm{C})+\rho\left(\mathrm{CH}_{3}\right)$ peak was occasionally observed, and corresponds to transverse optical $\mathrm{Si}-\mathrm{O}-\mathrm{Si}$ stretching, $v(\mathrm{Si}-\mathrm{O}-\mathrm{Si})_{\mathrm{TO}}$.
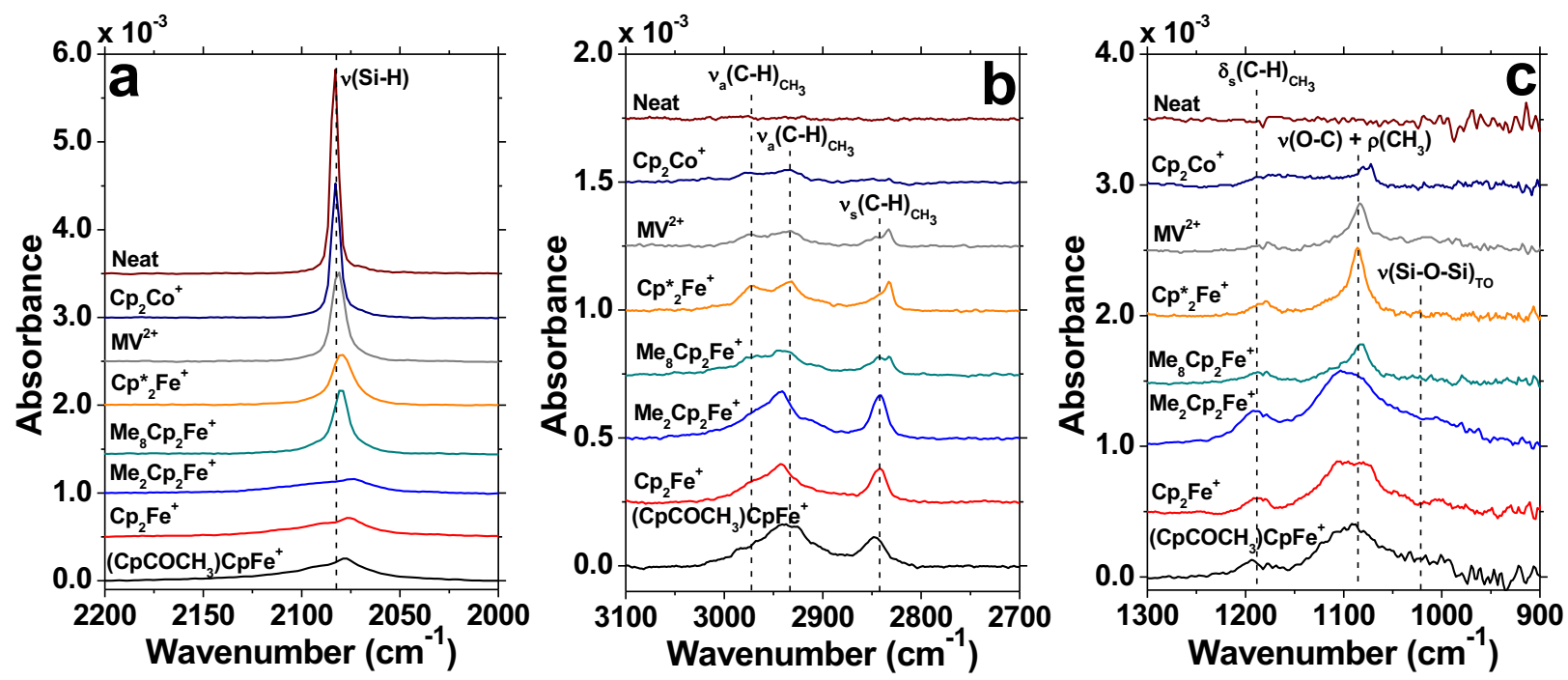

Figure 3. TIRS data for intrinsic $\mathrm{H}-\mathrm{Si}(111)$ surfaces after treatment in neat $\mathrm{CH}_{3} \mathrm{OH}$ or $\mathrm{CH}_{3} \mathrm{OH}$ containing $1.0 \mathrm{mM}$ of oxidant in the dark for 5 min. The $\mathrm{Si}-\mathrm{H}$ stretching peak (a), the $\mathrm{C}-\mathrm{H}$ stretching peaks (b), and the $\mathrm{C}-\mathrm{H}$ bending and $\mathrm{O}-\mathrm{C}$ stretching coupled with the $\mathrm{CH}_{3}$ rocking peaks (c) are shown with the oxidant indicated above each spectrum. The spectra are offset vertically for clarity. The symbols $v, \delta$, and $\rho$ denote stretching, bending, and rocking motions, respectively.

The transition from the broad, low-intensity $v(\mathrm{Si}-\mathrm{H})$ peak observed for reactions performed with $\mathrm{Me}_{2} \mathrm{Cp}_{2} \mathrm{Fe}^{+}$to the sharp peak observed for reactions performed with $\mathrm{Me}_{8} \mathrm{Cp}_{2} \mathrm{Fe}^{+}$ suggests a shift in the behavior of the reaction. The $v(\mathrm{Si}-\mathrm{H})$ peak generally sharpened gradually 
as $E^{\circ}\left(\mathrm{A} / \mathrm{A}^{-}\right)$decreased beyond $E^{\circ}\left(\mathrm{Me}_{8} \mathrm{Cp}_{2} \mathrm{Fe}^{+/ 0}\right)$. The overall peak shape for reactions performed with $\mathrm{Cp}_{2} \mathrm{Co}^{+}$was comparable to reactions performed in the absence of oxidant.

The intensity and width of the modes associated with the grafting of $-\mathrm{OCH}_{3}$ groups to the $\mathrm{H}-\mathrm{Si}(111)$ surface presented in Figure $3 \mathrm{~b}$ and Figure $3 \mathrm{c}$ were reduced for $\mathrm{Me}_{8} \mathrm{Cp}_{2} \mathrm{Fe}^{+}$and $\mathrm{Cp}_{2}{ }_{2} \mathrm{Fe}^{+}$compared with the peak areas observed for more oxidizing species. These spectral features were further decreased in intensity for reactions performed in solutions that contained $\mathrm{MV}^{2+}$, and reactions performed in neat $\mathrm{CH}_{3} \mathrm{OH}$ or in $\mathrm{CH}_{3} \mathrm{OH}$ that contained $\mathrm{Cp}_{2} \mathrm{Co}^{+}$yielded nearly undetectable $v(\mathrm{C}-\mathrm{H})_{\mathrm{CH}_{3}}, \delta_{\mathrm{s}}(\mathrm{C}-\mathrm{H})_{\mathrm{CH}_{3}}$, or $v(\mathrm{O}-\mathrm{C})+\rho\left(\mathrm{CH}_{3}\right)$ signals. These results indicate that the thermodynamic formal potential of oxidants with $E^{\circ}\left(\mathrm{A} / \mathrm{A}^{-}\right) \leq E^{\circ}\left(\mathrm{Me}_{8} \mathrm{Cp}_{2} \mathrm{Fe}^{+/ 0}\right)$ is not sufficient to efficiently promote oxidant-activated addition of $\mathrm{CH}_{3} \mathrm{OH}$ to $\mathrm{H}-\mathrm{Si}(111)$.

Figure $4 \mathrm{a}$ presents values of $\theta_{\mathrm{Si}-\mathrm{OCH}_{3}}$ determined from TIRS measurements as a function of the oxidizing conditions used for the reaction of $\mathrm{H}-\mathrm{Si}(111)$ with $\mathrm{CH}_{3} \mathrm{OH}$ for intrinsic, n-type, and p-type $\mathrm{H}-\mathrm{Si}(111)$ samples. The data presented in Figure $4 \mathrm{a}$ show a relatively constant $\theta_{\mathrm{Si}-}$ $\mathrm{OCH}_{3}$ for $\left(\mathrm{CpCOCH}_{3}\right) \mathrm{CpFe}^{+}, \mathrm{Cp}_{2} \mathrm{Fe}^{+}$, and $\mathrm{Me}_{2} \mathrm{Cp}_{2} \mathrm{Fe}^{+}$as the oxidant. A substantial decrease in $\theta_{\mathrm{Si}-}$ $\mathrm{OCH}_{3}$ was observed for reactions performed in $\mathrm{CH}_{3} \mathrm{OH}$ solutions that contained oxidants having $E^{\circ}\left(\mathrm{A} / \mathrm{A}^{-}\right) \leq E^{\circ}\left(\mathrm{Me}_{8} \mathrm{Cp}_{2} \mathrm{Fe}^{+/ 0}\right)$. This transition, which occurred for $E^{\circ}\left(\mathrm{A} / \mathrm{A}^{-}\right)$between $0.22 \mathrm{~V}$ and $-0.08 \mathrm{~V}$ vs SCE, is marked in Figure 4 by a vertical black dotted line. The general trend indicated that $\left(\mathrm{CpCOCH}_{3}\right) \mathrm{CpFe}^{+}, \mathrm{Cp}_{2} \mathrm{Fe}^{+}$, and $\mathrm{Me}_{2} \mathrm{Cp}_{2} \mathrm{Fe}^{+}$were capable of serving as electron acceptors in the reaction of $\mathrm{H}-\mathrm{Si}(111)$ with $\mathrm{CH}_{3} \mathrm{OH}$, while $\mathrm{Me}_{8} \mathrm{Cp}_{2} \mathrm{Fe}^{+}, \mathrm{Cp}_{2}{ }_{2} \mathrm{Fe}^{+}, \mathrm{MV}^{2+}$, and $\mathrm{Cp}_{2} \mathrm{Co}^{+}$were not effective oxidants in driving this reaction. 


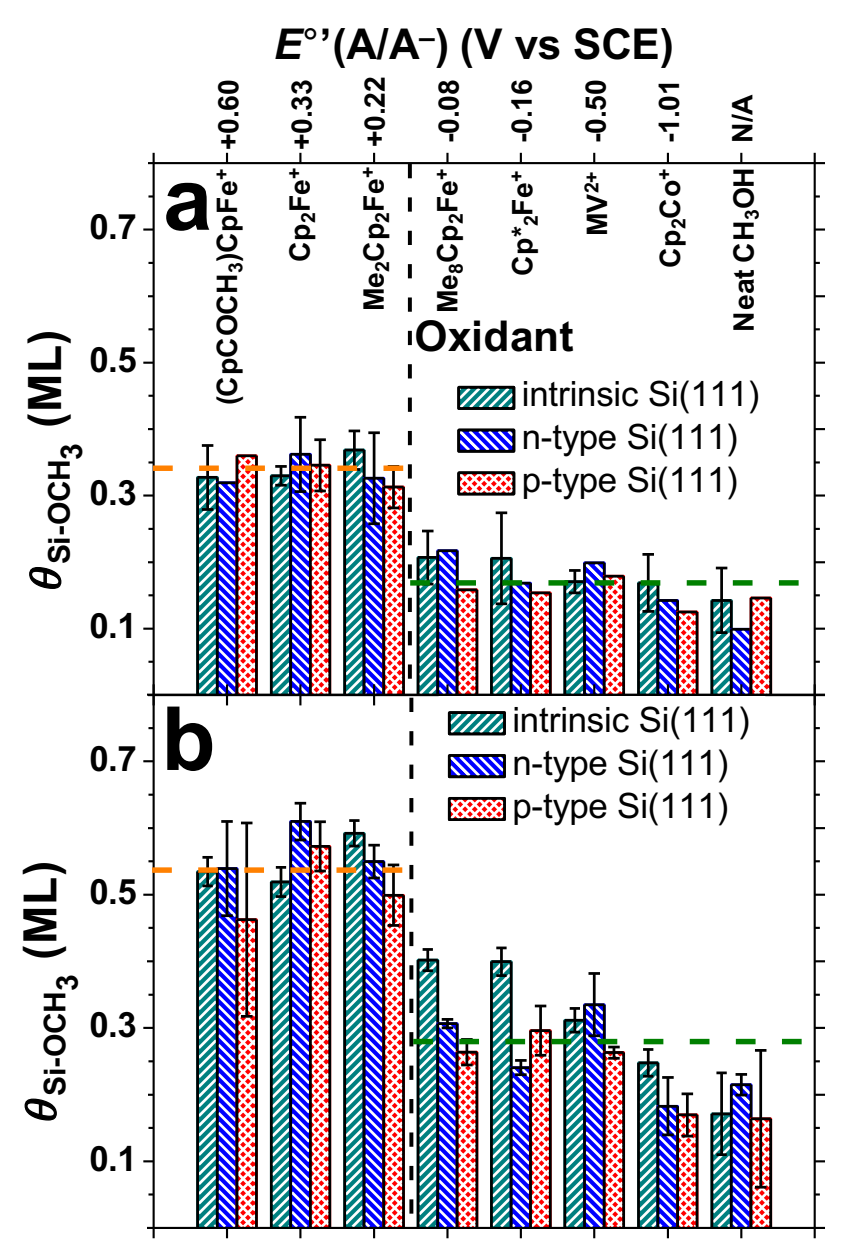

Figure 4. Correlation between $\theta_{\mathrm{Si}_{-} \mathrm{OCH}_{3}}$ and the oxidizing conditions used in the reaction of $\mathrm{H}-$ $\mathrm{Si}(111)$ surfaces with $\mathrm{CH}_{3} \mathrm{OH}$ in the dark. Reactions were performed for 5 min in neat $\mathrm{CH}_{3} \mathrm{OH}$ or $\mathrm{CH}_{3} \mathrm{OH}$ containing $1.0 \mathrm{mM}$ of the oxidant species indicated. The upper x-axis of panel a gives the oxidant used for each reaction in addition to the formal potential for each oxidant. Panel a gives $\theta_{\mathrm{Si}-\mathrm{OCH}_{3}}$ determined by TIRS measurements using eqs 5 and 6 , and panel $\mathrm{b}$ gives $\theta_{\mathrm{Si}-\mathrm{OCH}_{3}}$ determined by XPS measurements using eq 7. The orange and green dotted lines are averages of $\theta_{\mathrm{Si}-\mathrm{OCH}_{3}}$ for all samples left and right of the black dotted line, respectively. Error bars represent statistical variation across multiple samples, and data points with no error bars represent single measurements. The error for single measurements in panel a can be estimated as $\pm 0.3 \mathrm{ML}$ based on the average standard deviation across all samples. 
Figure $4 \mathrm{~b}$ presents values of $\theta_{\mathrm{Si}-\mathrm{OCH}_{3}}$ determined from XPS measurements as a function of the oxidizing conditions used. For all sample types, the values of $\theta_{\mathrm{Si}_{-} \mathrm{OCH}_{3}}$ determined by XPS were substantially larger than those determined using TIRS measurements. For reference, the C 1s core level XP spectra for representative $\mathrm{H}-\mathrm{Si}(111)$ samples after 5 min exposure to $\mathrm{CH}_{3} \mathrm{OH}$ solutions is shown in Figure S1 (Supporting Information). Adventitious hydrocarbon species, the majority of which are likely unbound $\mathrm{CH}_{3} \mathrm{OH}$ or THF, contributed to the XPS signal ascribable to $\mathrm{C}$ bound to $\mathrm{O}$, artifically increasing the value of $\theta_{\mathrm{Si}-\mathrm{OCH}_{3}}$ determined by XPS. The the results in Figure $4 \mathrm{~b}$ nevertheless show a large and relatively stable $\theta_{\mathrm{Si}-\mathrm{OCH}_{3}}$ for reactions performed in $\mathrm{CH}_{3} \mathrm{OH}$ solutions that contained $\left(\mathrm{CpCOCH}_{3}\right) \mathrm{CpFe}^{+}, \mathrm{Cp}_{2} \mathrm{Fe}^{+}$, or $\mathrm{Me}_{2} \mathrm{Cp}_{2} \mathrm{Fe}^{+}$as oxidants, with a marked decrease in $\theta_{\mathrm{Si}-\mathrm{OCH}_{3}}$ for reactions performed in $\mathrm{CH}_{3} \mathrm{OH}$ solutions that contained $\mathrm{Me}_{8} \mathrm{Cp}_{2} \mathrm{Fe}^{+}$. Compared with results for TIRS measurements, for oxidants with $E^{\circ}\left(\mathrm{A} / \mathrm{A}^{-}\right) \leq-0.08$ $\mathrm{V}$ vs SCE, the overall trend showed that $\theta_{\mathrm{Si}-\mathrm{OCH}_{3}}$ decreased more gradually as the formal potential of the oxidant in solution became less oxidizing.

Figure S2 (Supporting Information) presents the area under the $v(\mathrm{C}-\mathrm{H})_{\mathrm{CH}_{3}}$ peaks $(3050-$ $2800 \mathrm{~cm}^{-1}$ ) as a function of the oxidizing conditions used. These data parallel the XPS data presented in Figure 4b, with the largest peak areas observed for reactions performed in $\mathrm{CH}_{3} \mathrm{OH}$ solutions that contained $\left(\mathrm{CpCOCH}_{3}\right) \mathrm{CpFe}^{+}, \mathrm{Cp}_{2} \mathrm{Fe}^{+}$, and $\mathrm{Me}_{2} \mathrm{Cp}_{2} \mathrm{Fe}^{+}$as oxidants. Oxidants with $E^{\circ}\left(\mathrm{A} / \mathrm{A}^{-}\right) \leq-0.08 \mathrm{~V}$ vs SCE yielded a decreased $v(\mathrm{C}-\mathrm{H})_{\mathrm{CH}_{3}}$ peak area compared with the three most oxidizing species. The $v(\mathrm{C}-\mathrm{H})_{\mathrm{CH}_{3}}$ peak area, like the $\mathrm{C} 1 \mathrm{~s}$ photoemission signal, is sensitive to adventitious hydrocarbons, making absolute comparisons difficult. Nonetheless, the data indicate a trend showing a gradual decrease in the $v(\mathrm{C}-\mathrm{H})_{\mathrm{CH}_{3}}$ peak area as $E^{\circ}\left(\mathrm{A} / \mathrm{A}^{-}\right)$decreased, in agreement with the data presented in Figure 4. 
Figure S3 (Supporting Information) presents the area under the $\delta_{\mathrm{s}}(\mathrm{C}-\mathrm{H})_{\mathrm{CH}_{3}}$ and complex $v(\mathrm{C}-\mathrm{O})+\rho\left(\mathrm{CH}_{3}\right)$ peaks $\left(1250-950 \mathrm{~cm}^{-1}\right)$ as a function of the oxidizing conditions used. The results show a clear difference between oxidants having $E^{\circ}\left(\mathrm{A} / \mathrm{A}^{-}\right) \geq 0.22 \mathrm{~V}$ vs SCE and oxidants with $E^{\circ}\left(\mathrm{A} / \mathrm{A}^{-}\right) \leq-0.08 \mathrm{~V}$ vs SCE. Specifically, a substantial decrease in peak area was apparent between reactions performed in $\mathrm{CH}_{3} \mathrm{OH}$ solutions with $\mathrm{Me}_{2} \mathrm{Cp}_{2} \mathrm{Fe}^{+}$relative to reactions in $\mathrm{CH}_{3} \mathrm{OH}$ solutions with $\mathrm{Me}_{8} \mathrm{Cp}_{2} \mathrm{Fe}^{+}$. The data in Figure $\mathrm{S} 3$ closely parallel the observed trend in Figure 4a.

The TIRS peak area analysis data presented in Figure 4a and Figure S3 indicate that the oxidant-activated reaction of $\mathrm{H}-\mathrm{Si}(111)$ surfaces with $\mathrm{CH}_{3} \mathrm{OH}$ is not facilitated effectively by oxidants having $E^{\circ}\left(\mathrm{A} / \mathrm{A}^{-}\right) \leq E^{\circ}\left(\mathrm{Me}_{8} \mathrm{Cp}_{2} \mathrm{Fe}^{+/ 0}\right)$. Additionally, the data indicate that, in the dark, the reaction of $\mathrm{H}-\mathrm{Si}(111)$ samples with $\mathrm{CH}_{3} \mathrm{OH}$ under the specified conditions is independent of the dopant type and dopant density of the $\mathrm{Si}(111)$ substrate.

III.B. Reaction of $\mathrm{H}-\mathrm{Si}(111)$ with $\mathrm{CH}_{3} \mathrm{OH}$ Solutions in the Presence of Light. Figure 5 shows $\theta_{\mathrm{Si}-\mathrm{OCH}_{3}}$ determined by TIRS (eqs 5 and 6) as a function of the oxidizing conditions used for the reaction of $\mathrm{H}-\mathrm{Si}(111)$ with $\mathrm{CH}_{3} \mathrm{OH}$ in the dark or under ambient light. For intrinsic or ntype $\mathrm{H}-\mathrm{Si}(111)$ reacted in ambient light with $\mathrm{CH}_{3} \mathrm{OH}$ that contained $\mathrm{Me}_{8} \mathrm{Cp}_{2} \mathrm{Fe}^{+}, \mathrm{Cp}_{2} \mathrm{Fe}^{+}$or $\mathrm{Me}_{2} \mathrm{Cp}_{2} \mathrm{Fe}^{+}, \theta_{\mathrm{Si}-\mathrm{OCH}_{3}}$ increased relative to the same reaction in the dark. The values for $\theta_{\mathrm{Si}-\mathrm{OCH}_{3}}$ increased for these three oxidants, but the values for $\mathrm{Me}_{8} \mathrm{Cp}_{2} \mathrm{Fe}^{+}$were nevertheless smaller than that for $\mathrm{Cp}_{2} \mathrm{Fe}^{+}$or $\mathrm{Me}_{2} \mathrm{Cp}_{2} \mathrm{Fe}^{+}$. For solutions that contained $\mathrm{Cp}^{*}{ }_{2} \mathrm{Fe}^{+}, \mathrm{MV}^{2+}$, or $\mathrm{Cp}_{2} \mathrm{Co}^{+}$, intrinsic or n-type $\mathrm{H}-\mathrm{Si}(111)$ samples exhibited $\theta_{\mathrm{Si}-\mathrm{OCH}_{3}}$ that was close to the value observed in the dark. The results for $\mathrm{p}$-type $\mathrm{H}-\mathrm{Si}(111)$ surfaces in the light were not statistically different from the results observed in the dark. 


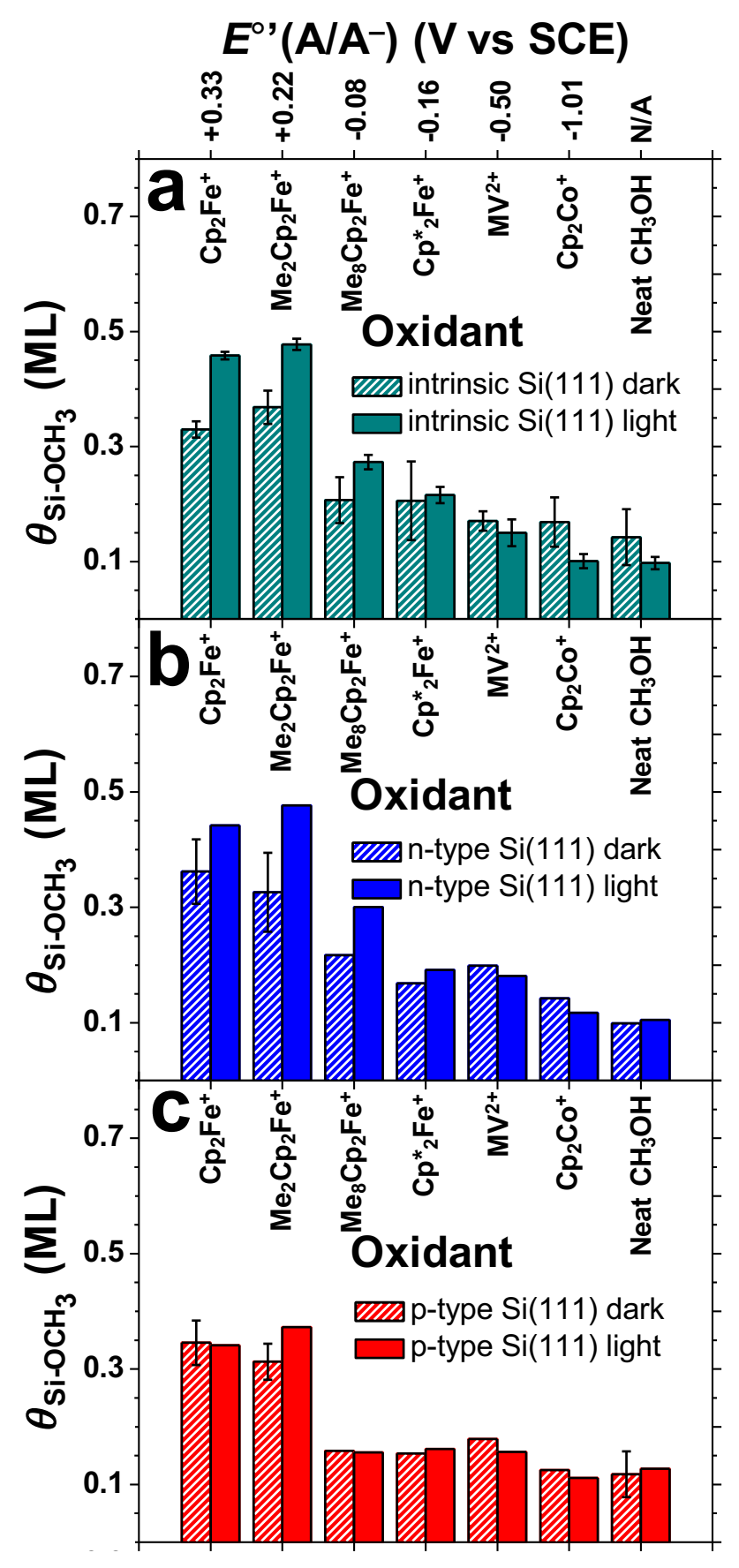

Figure 5. Correlation between $\theta_{\mathrm{Si}-\mathrm{OCH}_{3}}$ and the oxidizing conditions used in the reaction of (a) intrinsic, (b) n-type, and (c) p-type $\mathrm{H}-\mathrm{Si}(111)$ surfaces with $\mathrm{CH}_{3} \mathrm{OH}$ in the absence (striped) and presence (solid) of ambient light. Reactions were performed for 5 min in neat $\mathrm{CH}_{3} \mathrm{OH}$ or $\mathrm{CH}_{3} \mathrm{OH}$ containing $1.0 \mathrm{mM}$ of the oxidant specified at the top of each plot. Experimentally determined formal potentials, $E^{\circ}\left(\mathrm{A} / \mathrm{A}^{-}\right)$, for each oxidant are given above panel a. The values for $\theta_{\mathrm{Si}-\mathrm{OCH}_{3}}$ 
were determined by TIRS measurements using eqs 1 and 2. Error bars represent statistical variation across multiple samples, and data points with no error bars represent single measurements. The error for single measurements in panels $b$ and can be estimated as $\pm 0.3 \mathrm{ML}$ based on the average standard deviation across all samples.

The intrinsic samples, so called because of their low dopant density, were very lightly ndoped (Figure 2), implying that the valence-band states are fully occupied in the absence of illumination. The reactivity observed herein indicates that samples having Fermi levels situated positive of (above) the middle of the band gap, that is, intrinsic or n-type samples, exhibited an increased rate of methoxylation of $\mathrm{H}-\mathrm{Si}(111)$ surfaces in the presence of illumination relative to the rate of methoxylation in the dark.

III.C. Potentiostatic Reaction of $\mathrm{H}-\mathrm{Si}(111)$ with $\mathrm{CH}_{3} \mathrm{OH}$. The reaction of $\mathrm{H}-\mathrm{Si}(111)$ with $\mathrm{CH}_{3} \mathrm{OH}$ was investigated under applied external bias in the dark as well as under illumination. Figure 6 presents $J-E$ data for n-type and p-type H-Si(111) surfaces in contact with $\mathrm{CH}_{3} \mathrm{OH}$ solutions that contained $1.0 \mathrm{M} \mathrm{LiClO}_{4}$ as the supporting electrolyte. In the dark, the methoxylation of n-type $\mathrm{H}-\mathrm{Si}(111)$ was observed as a gradual increase in current starting near $-0.4 \mathrm{~V}$ vs SCE, with a peak observed at $-0.08 \mathrm{~V}$ vs SCE. A gradual decline in current was observed past the peak current, suggesting that the initial rise in current arose from methoxylation of $\mathrm{H}-\mathrm{Si}(111)$ surfaces. Under illumination, n-type H-Si(111) surfaces showed much higher current density, in addition to a sharp peak centered at $-0.17 \mathrm{~V}$ vs SCE that is consistently assigned to the methoxylation of $\mathrm{H}-\mathrm{Si}(111)$ surfaces. At more positive potentials, a rapid rise in current density was observed beginning at $0 \mathrm{~V}$ vs SCE, and was indicative of subsurface oxidation of the $\operatorname{Si}(111)$ substrate. 


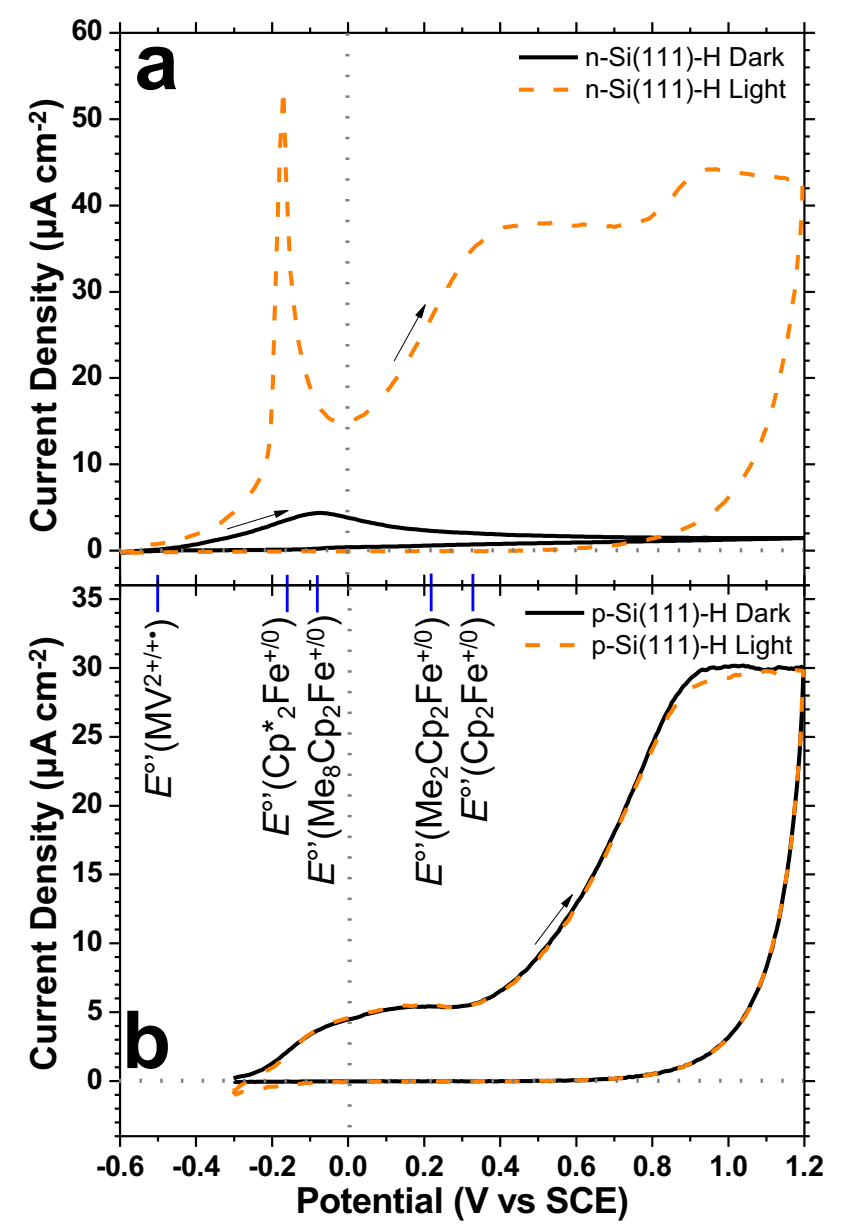

Figure 6. $J-E$ behavior of (a) n-type and (b) p-type $\mathrm{H}-\mathrm{Si}(111)$ samples in contact with $\mathrm{CH}_{3} \mathrm{OH}$ solutions containing 1.0 $\mathrm{M} \mathrm{LiClO}_{4}$ as supporting electrolyte. Data collected in the dark (solid black) and under $10 \mathrm{~mW} \mathrm{~cm}{ }^{-2}$ of simulated solar illumination (dashed orange) are shown. The formal potentials of the oxidants used in this work are indicated by the vertical blue lines at the top of panel $b$.

For p-type $\mathrm{H}-\mathrm{Si}(111)$, a gradual increase in current density that is assigned to methoxylation was observed near $-0.2 \mathrm{~V}$ vs SCE. A distinct peak current due to the methoxylation reaction was not observed, as the onset of the subsurface oxidation of the H$\mathrm{Si}(111)$ substrate was observed near $+0.4 \mathrm{~V}$ vs SCE. The results indicate that the methoxylation 
of p-type H-Si(111) samples was not sensitive to illumination, as the dark and light curves in Figure $6 \mathrm{~b}$ overlapped substantially. A second sweep of the n-type and p-type electrodes in Figure 6 (not shown) was flat through the region ascribed to potentiostatic methoxylation.

Table 1 summarizes the quantification of the current passed for the region assigned to the methoxylation of $\mathrm{H}-\mathrm{Si}(111)$ surfaces. The quantification of $\theta_{\mathrm{Si}-\mathrm{OCH}_{3}}$ assumed that 2 electrons were passed for the reaction of each surface site with $\mathrm{CH}_{3} \mathrm{OH}$. The $\theta_{\mathrm{Si}-\mathrm{OCH}_{3}}$ resulting from potentiostatic methoxylation of n-type $\mathrm{H}-\mathrm{Si}(111)$ surfaces in the dark was comparable to $\theta_{\mathrm{Si}-\mathrm{OCH}_{3}}$ obtained from potentiostatic methoxylation of p-type H-Si(111) surfaces in the dark as well as under illumination. In contrast, illuminated n-type H-Si(111) surfaces showed significantly greater anodic current that resulted in higher $\theta_{\mathrm{Si}-\mathrm{OCH}_{3}}$ compared with samples that were methoxylated in the dark.

The potential at which half of the current ascribed to the methoxylation reaction had been passed $\left(E_{1 / 2}\right)$ is specified in Table 1 . For multiple samples, $E_{1 / 2}$ was the same within error for ntype samples in the dark and p-type samples in the dark or under illumination. For n-type samples under illumination, $E_{1 / 2}$ was shifted by $-0.17 \pm 0.05 \mathrm{~V}$ compared with n-type samples in the dark, indicating the presence of a photovoltage at the n-Si interface that produced higher anodic current densities and consequently shifted $E_{1 / 2}$ to more negative potentials. 
Table 1. Summary of the Quantification for the Potentiostatic Methoxylation of H-Si(111) Surfaces.

\begin{tabular}{llllc}
\hline $\begin{array}{c}\text { Dopant } \\
\text { Type }\end{array}$ & Illumination & $\begin{array}{l}\text { Potential Range } \\
\text { Quantified }(\mathbf{V})^{\boldsymbol{a}}\end{array}$ & $\boldsymbol{\theta}_{\mathrm{Si-OCH}}(\mathbf{M L})^{b}$ & Potential at Half \\
\hline n-type & Dark & -0.4 to +0.6 & $0.22 \pm 0.05$ & $\boldsymbol{\theta}_{\mathrm{Si-OCH}}(\mathbf{V})^{c}$ \\
n-type & $10 \mathrm{~mW} \mathrm{~cm}^{-2}$ & -0.3 to 0 & $0.39 \pm 0.07$ & $-0.17 \pm 0.05$ \\
p-type & Dark & -0.2 to +0.3 & $0.23 \pm 0.06$ & $+0.02 \pm 0.04$ \\
p-type & $10 \mathrm{~mW} \mathrm{~cm}^{-2}$ & -0.2 to +0.3 & $0.20 \pm 0.01$ & $+0.02 \pm 0.06$ \\
\hline
\end{tabular}

${ }^{a}$ Potential vs SCE. ${ }^{b}$ Quantified based on anodic current passed assuming 2 electrons per surface site that reacts with $\mathrm{CH}_{3} \mathrm{OH}$. The density of surface sites on the $\mathrm{Si}(111)$ surface is $7.83 \times 10^{14}$ $\mathrm{cm}^{-2},{ }^{46}$ requiring $2.51 \times 10^{-4} \mathrm{C} \mathrm{cm}^{-2}$ to methoxylate all surface sites. ${ }^{c}$ Potential vs SCE at which half the charge attributed to the methoxylation of the surface was passed $\left(E_{1 / 2}\right)$. The values of $\theta_{\mathrm{Si}-}$ $\mathrm{OCH}_{3}$ and $E_{1 / 2}$ were quantified without use of a baseline to subtract current resulting from subsurface $\mathrm{SiO}_{\mathrm{x}}$ formation. To account for this, the regions quantified were selected to include a fraction of current from $\mathrm{SiO}_{\mathrm{x}}$ formation and excluded a roughly equivalent amount of current from the methoxylation reaction where applicable.

\section{DISCUSSION}

IV.A. Conditions that Lead to Methoxylation of the H-Si(111) Surface. The data reported in this work support previous reports that collectively indicate the presence of two reaction pathways, with mutually different relative rates of electron transfer, for the methoxylation of $\mathrm{H}-\mathrm{Si}(111)$. Both reaction pathways involve a net loss of 2 electrons per methoxylated $\mathrm{H}-\mathrm{Si}(111)$ surface site, with the electrons producing $\mathrm{H}_{2}$ in Scheme 1 or reducing 
two equivalents of oxidant in Scheme 2. When a molecular oxidant with a sufficiently positive $E^{\circ}\left(\mathrm{A} / \mathrm{A}^{-}\right)$is present in solution, as indicated in Scheme 2, the surface is more readily oxidized and reacts rapidly with methanol. This section of the discussion develops the kinetic model for charge transfer at the $\mathrm{H}-\mathrm{Si}(111)$ interface that accounts for these two charge-transfer reaction pathways.

Figure 7 depicts representative band structures for n-type and p-type Si surfaces in the dark and under illumination. We postulate that the methoxylation of $\mathrm{H}-\mathrm{Si}(111)$ surfaces can be broken into two half-reactions. The first half-reaction is the oxidation of the Si surface by the Si bulk. The oxidation energy for the $\mathrm{H}-\mathrm{Si}(111)$ surface $\left(\mathbf{E}\left(\mathrm{Si}^{+/ 0}\right)\right)$ is estimated using the value of $E_{1 / 2}$ determined by potentiostatic methoxylation (Table 1). As $E_{1 / 2}$ measured in the dark falls near $0 \mathrm{~V}$ vs $\mathrm{SCE}, \mathbf{E}\left(\mathrm{Si}^{+/ 0}\right)$ is estimated using eq 4 to lie within the $\mathrm{Si}$ band gap, at $\sim-4.7 \mathrm{eV}$. The electrons that comprise this electronic state are likely associated with a surface resonance that has been identified on the H-Si(111) surface. ${ }^{74}$ This surface resonance has been estimated to lie $\sim 0.1 \mathrm{eV}$ below $\mathbf{E}_{\mathrm{vb}}$ in vacuum, ${ }^{74-76}$ but hydrogen bonding between $\mathrm{CH}_{3} \mathrm{OH}$ and the $\mathrm{H}-\mathrm{Si}(111)$ surface is predicted to increase the electron density at the Si surface, shifting the electrons in the surface resonance more positive in energy. Oxidation of the surface resonance completes the first half of the proposed pathway, leading to methoxylation of the $\mathrm{H}-\mathrm{Si}(111)$ surface. 


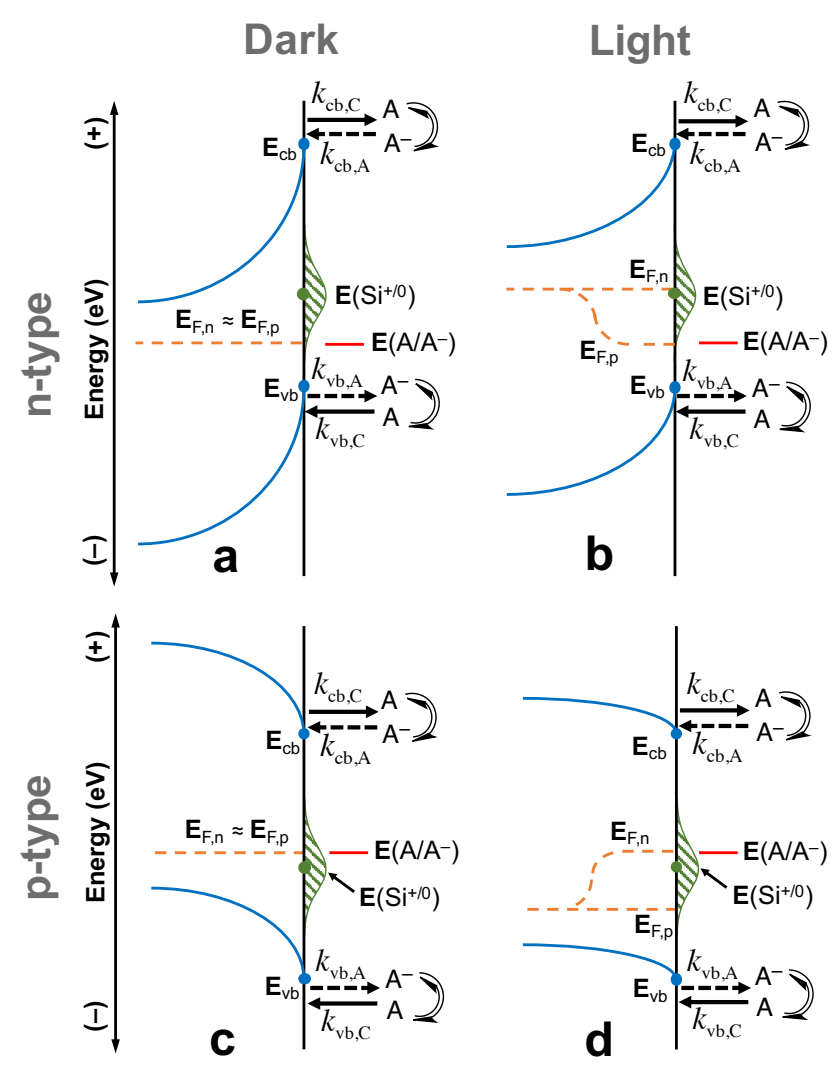

Figure 7. Schematic representation of charge transfer across a semiconductor/liquid interface for oxidant-activated methoxylation. The energy positions for the semiconductor valence band $\left(\mathbf{E}_{\mathrm{vb}}\right)$, conduction band $\left(\mathbf{E}_{\mathrm{cb}}\right)$, electron quasi-Fermi level $\left(\mathbf{E}_{\mathrm{F}, \mathrm{n}}\right)$, hole quasi-Fermi level $\left(\mathbf{E}_{\mathrm{F}, \mathrm{p}}\right)$, the oxidation energy of the surface $\mathrm{Si}\left(\mathbf{E}\left(\mathrm{Si}^{+/ 0}\right)\right)$, and solution energy $\left(\mathbf{E}\left(\mathrm{A} / \mathrm{A}^{-}\right)\right)$are indicated. The rate constants for cathodic and anodic charge transfer to and from the valence band are $k_{\mathrm{vb}, \mathrm{C}}$ and $k_{\mathrm{vb}, \mathrm{A}}$, respectively, and the rate constants for cathodic and anodic charge transfer from and to the conduction band are $k_{\mathrm{cb}, \mathrm{C}}$ and $k_{\mathrm{cb}, \mathrm{A}}$, respectively. Solid and dashed arrows indicate cathodic and anodic charge transfer, respectively. Panels a and c give the band structure for n-type and p-type, contacts, respectively, in the dark, and panels b and d show the same contacts in a and c, respectively, under illumination. 
Conditions that lead to oxidation of the surface can be described using a charge-transfer kinetics model. The theoretically expected ratios of the cathodic to anodic current density, which describe the direction and magnitude of current flow between surface resonance $\left(\mathbf{E}\left(\mathrm{Si}^{+/ 0}\right)\right)$ and the Si valence band or conduction band ( $R_{\mathrm{vb}, \mathrm{SR}}$ or $R_{\mathrm{cb}, \mathrm{SR}}$, respectively) are given in eqs 8 and 9:

$$
\begin{aligned}
& R_{\mathrm{vb}, \mathrm{SR}}=e^{\left(\frac{\mathbf{E}_{\mathrm{F}, \mathrm{p}}-\mathbf{E}\left(\mathrm{Si}^{+/ 0}\right)}{k_{\mathrm{B}} T}\right)} \\
& R_{\mathrm{cb}, \mathrm{SR}}=e^{\left(\frac{\mathbf{E}_{\mathrm{F}, \mathrm{n}}-\mathbf{E}\left(\mathrm{Si}^{+/ 0}\right)}{k_{\mathrm{B}} T}\right)}
\end{aligned}
$$

where $\mathbf{E}_{\mathrm{F}, \mathrm{p}}$ and $\mathbf{E}_{\mathrm{F}, \mathrm{n}}$ are the hole and electron quasi-Fermi levels, respectively. The derivation of eqs 8 and 9 is given in the Supporting Information. When $\mathbf{E}_{\mathrm{F}, \mathrm{p}}<\mathbf{E}\left(\mathrm{Si}^{+/ 0}\right)$ and $\mathbf{E}_{\mathrm{F}, \mathrm{n}}<\mathbf{E}\left(\mathrm{Si}^{+/ 0}\right)$, $R_{\mathrm{vb}, \mathrm{SR}}<1$ and $R_{\mathrm{cb}, \mathrm{SR}}<1$, respectively, and oxidation of the surface resonance dominates the charge-transfer process. Conversely, when $\mathbf{E}_{\mathrm{F}, \mathrm{p}}>\mathbf{E}\left(\mathrm{Si}^{+/ 0}\right)$ and $\mathbf{E}_{\mathrm{F}, \mathrm{n}}>\mathbf{E}\left(\mathrm{Si}^{+/ 0}\right), R_{\mathrm{vb}, \mathrm{SR}}>1$ and $R_{\mathrm{cb}, \mathrm{SR}}>1$, respectively, and according to eqs 8 and 9 , the surface is not readily oxidized by the bulk Si.

The second half of the methoxylation reaction is the reduction of a species in solution by electrons in the bulk, maintaining charge neutrality in the Si. When a well-defined solution energy $\left(\mathbf{E}\left(\mathrm{A} / \mathrm{A}^{-}\right)\right)$is produced by a molecular oxidant in solution, the cathodic to anodic current density ratios that describe the direction and magnitude of current flow between the Si valence band or conduction band ( $R_{\mathrm{vb}, \mathrm{sol}}$ or $R_{\mathrm{cb}, \text { sol }}$, respectively) and a solution with energy $\mathbf{E}\left(\mathrm{A} / \mathrm{A}^{-}\right)$are given by eqs 10 and 11 :

$$
\begin{aligned}
& R_{\mathrm{vb}, \mathrm{sol}}=e^{\left(\frac{\mathbf{E}_{\mathrm{F}, \mathrm{p}}-\mathbf{E}\left(\mathrm{A} / \mathrm{A}^{-}\right)}{k_{\mathrm{B}} T}\right)} \\
& R_{c \mathrm{~b}, \mathrm{sol}}=e^{\left(\frac{\mathbf{E}_{\mathrm{F}, \mathrm{n}}-\mathbf{E}\left(\mathrm{A} / \mathrm{A}^{-}\right)}{k_{\mathrm{B}} T}\right)}
\end{aligned}
$$


Eqs 10 and 11 are derived in the Supporting Information. For $\mathbf{E}_{\mathrm{F}, \mathrm{p}}<\mathbf{E}\left(\mathrm{A} / \mathrm{A}^{-}\right)$and $\mathbf{E}_{\mathrm{F}, \mathrm{n}}<\mathbf{E}\left(\mathrm{A} / \mathrm{A}^{-}\right)$, $R_{\mathrm{vb}, \mathrm{sol}}<1$ and $R_{\mathrm{cb}, \text { sol }}<1$, respectively, and species in solution are not readily reduced by the $\mathrm{Si}$. Conversely, when $\mathbf{E}_{\mathrm{F}, \mathrm{p}}>\mathbf{E}\left(\mathrm{A} / \mathrm{A}^{-}\right)$and $\mathbf{E}_{\mathrm{F}, \mathrm{n}}>\mathbf{E}\left(\mathrm{A} / \mathrm{A}^{-}\right), R_{\mathrm{vb}, \text { sol }}>1$ and $R_{\mathrm{cb}, \text { sol }}>1$, respectively, cathodic current flow to the solution readily occurs, and the oxidants in solution are reduced to complete the second half of the methoxylation reaction. In this framework, oxidant-activated methoxylation is obtained when the $\mathrm{Si}$ surface resonance is readily oxidized by the Si bulk $\left(R_{\mathrm{vb}, \mathrm{SR}}<1\right.$ and/or $\left.R_{\mathrm{cb}, \mathrm{SR}}<1\right)$ and concomitantly when the oxidants in solution are readily reduced by the $\operatorname{Si}$ bulk $\left(R_{\mathrm{vb}, \mathrm{sol}}>1\right.$ and/or $\left.R_{\mathrm{cb}, \mathrm{sol}}>1\right)$. When one or both of these conditions is not met, the methoxylation reaction is postulated to proceed according to Scheme 1.

When no oxidant was present in solution, or when the oxidant in solution was not sufficiently oxidizing, the reaction of $\mathrm{H}-\mathrm{Si}(111)$ surfaces with $\mathrm{CH}_{3} \mathrm{OH}$ occurred slowly, and the reaction rate was not responsive to changes in the dopant type or concentration or the presence of illumination. Because changes in the semiconductor bulk Fermi level had no effect on the rate of methoxylation in these cases, the rate of oxidation of the Si surface resonance by the Si bulk (eqs 8 and 9) appears to have minimal influence on the rate of methoxylation. Instead, for these cases, the rate of methoxylation appears to be limited by the reduction of the $\mathrm{Si}-\mathrm{H}$ and $\mathrm{O}-\mathrm{H}$ bonds to produce $\mathrm{H}_{2}$. The observations are consistent with expectations that the reduction of $\mathrm{Si}-\mathrm{H}$ and $\mathrm{O}-\mathrm{H}$ bonds to form $\mathrm{H}_{2}$ is kinetically slower than reduction of one-electron molecular oxidants that provide sufficiently oxidizing solution potentials to allow for facile methoxylation of the H-Si(111) surface. The methoxylation pathway depicted in Scheme 1 is postulated to occur under all conditions used herein, and, when the oxidizing environment favors oxidant-activated methoxylation (Scheme 2), both methoxylation pathways occur simultaneously. 
IV.B. Oxidant-Activated Methoxylation in the Dark. In the dark, intrinsic, n-type, and p-type samples exhibited similar methoxylation behavior, with solutions containing $\left(\mathrm{CpCOCH}_{3}\right) \mathrm{CpFe}^{+}, \mathrm{Cp}_{2} \mathrm{Fe}^{+}$, and $\mathrm{Me}_{2} \mathrm{Cp}_{2} \mathrm{Fe}^{+}$yielding increased rates of reaction compared with solutions that contained weaker oxidants. For all oxidants except $\left(\mathrm{CpCOCH}_{3}\right) \mathrm{CpFe}^{+/ 0}$, only the oxidized form was added to the solution, giving a Nernstian solution potential that was shifted positive of the $E^{\circ}\left(\mathrm{A} / \mathrm{A}^{-}\right)$value given in Figure 2. Assuming that the reduced species were present as contaminants with an oxidized/reduced ratio of $\sim 100: 1$, the Nernstian solution potentials would then be shifted by $\sim 0.12 \mathrm{~V}$ relative to the formal reduction potential. In the case of $\left(\mathrm{CpCOCH}_{3}\right) \mathrm{CpFe}^{+/ 0}$, the oxidized/reduced ratio was 1:9, yielding a Nernstian solution potential $E\left(\left(\mathrm{CpCOCH}_{3}\right) \mathrm{CpFe}^{+/ 0}\right)=+0.54 \mathrm{~V}$ vs SCE.

For oxidants that produce $\mathbf{E}\left(\mathrm{A} / \mathrm{A}^{-}\right)$sufficiently positive of $\mathbf{E}_{\mathrm{vb}}$, as indicated for n-type and p-type samples in Figure 7a and 7c, respectively, the semiconductor dopant atoms can ionize and shift the quasi-Fermi level positions at the surface, yielding $\mathbf{E}_{\mathrm{F}, \mathrm{p}}=\mathbf{E}_{\mathrm{F}, \mathrm{n}}=\mathbf{E}\left(\mathrm{A} / \mathrm{A}^{-}\right)$after equilibrium is reached. Under these conditions, the oxidant-activated pathway for methoxylation is inactive. Although the quasi-Fermi levels in this case can independently reach equilibrium with the solution energy, equilibrium between the bulk and the surface resonance is not necessarily achieved. Despite this, when $\mathbf{E}_{\mathrm{F}, \mathrm{p}}=\mathbf{E}_{\mathrm{F}, \mathrm{n}}=\mathbf{E}\left(\mathrm{A} / \mathrm{A}^{-}\right)$, there is no propensity for the $\mathrm{Si}$ to reduce oxidants in solution (eqs 10 and 11), and electrons are forced down the pathway that produces $\mathrm{H}_{2}$ (Scheme 1).

As $\mathbf{E}\left(\mathrm{A} / \mathrm{A}^{-}\right)$shifts more negative, approaching $\mathbf{E}_{\mathrm{vb}}$, the dopants become less effective at equilibrating $\mathbf{E}_{\mathrm{F}, \mathrm{p}}$ and $\mathbf{E}_{\mathrm{F}, \mathrm{n}}$ with the solution energy, and $\mathbf{E}_{\mathrm{F}, \mathrm{p}}$ and $\mathbf{E}_{\mathrm{F}, \mathrm{n}}$ begin to fall positive of $\mathbf{E}\left(\mathrm{A} / \mathrm{A}^{-}\right)$. With $\mathbf{E}_{\mathrm{F}, \mathrm{p}}>\mathbf{E}\left(\mathrm{A} / \mathrm{A}^{-}\right)$and $\mathbf{E}_{\mathrm{F}, \mathrm{n}}>\mathbf{E}\left(\mathrm{A} / \mathrm{A}^{-}\right)$, eqs 10 and 11 indicate that cathodic current flows from the Si to the solution. For $\mathbf{E}\left(\mathrm{A} / \mathrm{A}^{-}\right)$near $\mathbf{E}_{\mathrm{vb}}, \mathbf{E}_{\mathrm{F}, \mathrm{p}}$ and $\mathbf{E}_{\mathrm{F}, \mathrm{n}}$ are moved negative of 
$\mathbf{E}\left(\mathrm{Si}^{+/ 0}\right)$, and oxidation of the surface resonance occurs by eqs 8 and 9 . Under this situation, with $\mathbf{E}\left(\mathrm{A} / \mathrm{A}^{-}\right)$near or negative of $\mathbf{E}_{\mathrm{vb}}$, the conditions for the oxidant-activated methoxylation of the $\mathrm{H}-\mathrm{Si}(111)$ surface are satisfied. This framework therefore accounts for the observation of oxidant-activated methoxylation occurring for solutions containing $\left(\mathrm{CpCOCH}_{3}\right) \mathrm{CpFe}^{+}, \mathrm{Cp}_{2} \mathrm{Fe}^{+}$, and $\mathrm{Me}_{2} \mathrm{Cp}_{2} \mathrm{Fe}^{+}$, which effect $\mathbf{E}\left(\mathrm{A} / \mathrm{A}^{-}\right)$near $\mathbf{E}_{\mathrm{vb}}$.

IV.C. Oxidant-Activated Methoxylation in the Light. Examples of illuminated n-type and p-type Si interfaces are depicted in Figure $7 \mathrm{~b}$ and $7 \mathrm{~d}$, respectively. Illumination of n-type interfaces effectively shifts $\mathbf{E}_{\mathrm{F}, \mathrm{n}}$ positive as the electron concentration at the surface increases. This positive shift in $\mathbf{E}_{\mathrm{F}, \mathrm{n}}$ yields $R_{\mathrm{cb} \text {,sol }}>1$, and cathodic current from the conduction band can complete the reduction half of the methoxylation reaction. For weak oxidants with $\mathbf{E}\left(\mathrm{A} / \mathrm{A}^{-}\right)$ positive of $\mathbf{E}\left(\mathrm{Si}^{+/ 0}\right), \mathbf{E}_{\mathrm{F}, \mathrm{p}}$ at n-type interfaces will not be capable of oxidizing the surface resonance, and the oxidant-activated methoxylation reaction is inactive even under illumination. When the solution potential is capable of shifting $\mathbf{E}_{\mathrm{F}, \mathrm{p}}$ negative of $\mathbf{E}\left(\mathrm{Si}^{+/ 0}\right)$, the oxidant-activated mechanism can become active at n-type interfaces under illumination. For example, solutions containing $\mathrm{Me}_{8} \mathrm{Cp}_{2} \mathrm{Fe}^{+}$yielded an increased rate of methoxylation at illuminated n-type surfaces, while solutions containing $\mathrm{Cp}_{2} * \mathrm{Fe}^{+}$showed no obvious sensitivity to light.

Illumination of p-type interfaces results in an increase in the hole concentration at the surface, shifting $\mathbf{E}_{\mathrm{F}, \mathrm{p}}$ negative, as shown in Figure $7 \mathrm{~d}$. This decrease in $\mathbf{E}_{\mathrm{F}, \mathrm{p}}$ allows for oxidation of the surface resonance for oxidants that effect $\mathbf{E}\left(\mathrm{A} / \mathrm{A}^{-}\right)$positive of $\mathbf{E}\left(\mathrm{Si}^{+/ 0}\right)$ by eq 8 . However, illumination of p-type samples has a negligible effect on the position of $\mathbf{E}_{\mathrm{F}, \mathrm{n}}$ relative to $\mathbf{E}\left(\mathrm{A} / \mathrm{A}^{-}\right)$, and the rate of reduction of the oxidants in solution by the Si bulk is unchanged by eq 11 . Thus, the reduction half-reaction required for oxidant-activated methoxylation is not affected by illumination at p-type interfaces. 
IV.D. Potentiostatic Methoxylation in the Dark. Si electrodes that are electrically connected to an external circuit via an ohmic contact at the back of the wafer require different considerations than wafers that are electrically isolated in solution. For wafers connected to a potentiostat, charge neutrality of the Si surface can be maintained at the back of the electrode by movement of charge carriers through the external circuit to the counter electrode. The methoxylation reaction requires anodic current flow at the working electrode to oxidize the surface resonance, and electrons generated by this oxidation process can flow through the external circuit to the counter electrode. Thus, only eqs 8 and 9 , which describe oxidation of the surface resonance, need to be considered in the potentiostatic methoxylation of $\mathrm{H}-\mathrm{Si}(111)$ electrodes.

Potentiostatic methoxylation of n-type and p-type Si samples in the dark resulted in similar values for $\theta_{\mathrm{Si}-\mathrm{OCH}_{3}}$ and $E_{1 / 2}$. The experimentally determined value for $E_{1 / 2}$ was $\sim 0 \mathrm{~V}$ vs SCE for both n-type and p-type samples. Assuming $-q E_{1 / 2}=\mathbf{E}\left(\mathrm{Si}^{+/ 0}\right)$, the oxidation potential of the surface lies between $-q E^{\circ}\left(\mathrm{Me}_{2} \mathrm{Cp}_{2} \mathrm{Fe}^{+/ 0}\right)$ and $-q E^{\circ}\left(\mathrm{Me}_{8} \mathrm{Cp}_{2} \mathrm{Fe}^{+/ 0}\right)$. For potentiostatic methoxylation, the Fermi level at the surface is controlled by the applied potential, $E_{\text {app}}$, analogous to Figure $7 \mathrm{a}$ and $\mathrm{c}$ (where $-q E_{\text {app }}$ replaces $\mathbf{E}\left(\mathrm{A} / \mathrm{A}^{-}\right)$). As $-q E_{\text {app }}$ moves in the negative direction ( $E_{\mathrm{app}}$ sweeping positive) and $\mathbf{E}_{\mathrm{F}, \mathrm{p}}$ and $\mathbf{E}_{\mathrm{F}, \mathrm{n}}$ approach $\mathbf{E}\left(\mathrm{Si}^{+/ 0}\right)$, oxidation of the surface resonance becomes favorable by eqs 8 and 9 . The reductive half of the methoxylation mechanism is satisfied by the ohmic contact at the back of the electrode, and potentiostatic methoxylation of the $\mathrm{H}-\mathrm{Si}(111)$ surface proceeds. Thus, in the dark, both n-type and p-type samples exhibit similar results for potentiostatic methoxylation.

IV.E. Potentiostatic Methoxylation in the Light. Illuminated semiconductor interfaces under applied external bias differ from electrically isolated semiconductor interfaces in solution. 
Under applied external bias, illuminated semiconductors exhibit quasi-Fermi level splitting such that the majority-carrier Fermi level is controlled by $E_{\text {app, }}$, thereby determining the level of bandbending at the interface. Figure 8a illustrates that $\mathbf{E}_{\mathrm{F}, \mathrm{p}}$ moves more negative at illuminated n-type samples, allowing oxidation of the surface resonance at more positive $-q E_{\text {app }}$ than in the dark according to eq 8 . This expectation is consistent with the observed shift in $E_{1 / 2}$ from $0 \mathrm{~V}$ vs SCE in the dark to $-0.17 \mathrm{~V}$ vs SCE under illumination for n-type samples (Table 1). Additionally, the decrease in $\mathbf{E}_{\mathrm{F}, \mathrm{p}}$ at illuminated n-type interfaces nearly doubled $\theta_{\mathrm{Si}-\mathrm{OCH}_{3}}$ compared with n-type samples in the dark, thus indicating an increased rate of methoxylation at illuminated n-type interfaces facilitated by the splitting of the quasi-Fermi levels.
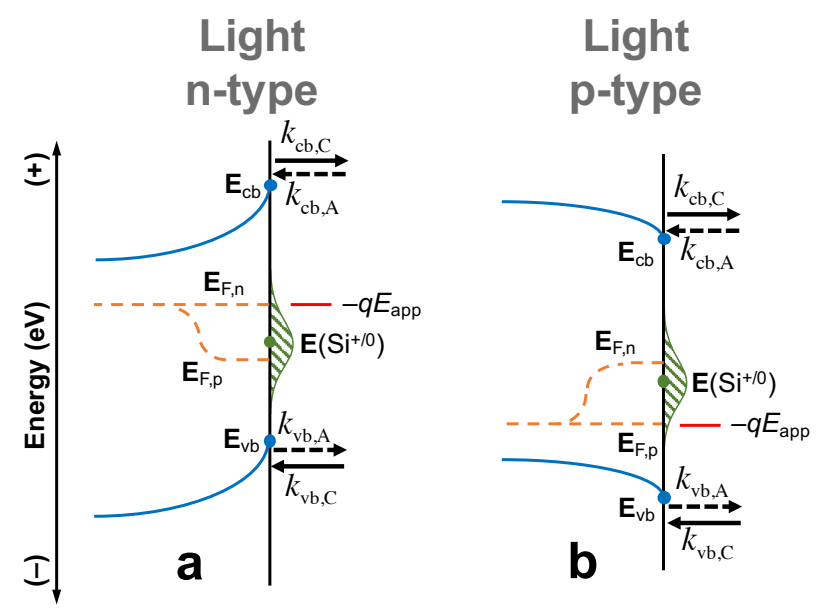

Figure 8. Schematic representation of the interfacial energetics at illuminated (a) n-type and (b) p-type semiconductor/liquid interfaces under applied external bias. The energy positions for the semiconductor valence band $\left(\mathbf{E}_{\mathrm{vb}}\right)$, conduction band $\left(\mathbf{E}_{\mathrm{cb}}\right)$, electron quasi-Fermi level $\left(\mathbf{E}_{\mathrm{F}, \mathrm{n}}\right)$, hole quasi-Fermi level $\left(\mathbf{E}_{\mathrm{F}, \mathrm{p}}\right)$, the oxidation energy of the surface $\mathrm{Si}\left(\mathbf{E}\left(\mathrm{Si}^{+/ 0}\right)\right)$, and applied external potential $\left(-q E_{\mathrm{app}}\right)$ are indicated. The rate constants for cathodic and anodic charge transfer to and from the valence band are $k_{\mathrm{vb}, \mathrm{C}}$ and $k_{\mathrm{vb}, \mathrm{A}}$, respectively, and the rate constants for cathodic and anodic charge transfer from and to the conduction band are $k_{\mathrm{cb}, \mathrm{C}}$ and $k_{\mathrm{cb}, \mathrm{A}}$, respectively. Solid and dashed arrows indicate cathodic and anodic charge transfer, respectively. 
Illuminated p-type interfaces, in contrast, exhibit an increase in $\mathbf{E}_{\mathrm{F}, \mathrm{n}}$ at the surface, whereas $\mathbf{E}_{\mathrm{F}, \mathrm{p}}$ is controlled by $-q E_{\mathrm{app}}$, as indicated in Figure $8 \mathrm{~b}$. The increase in $\mathbf{E}_{\mathrm{F}, \mathrm{n}}$ does not affect the rate of oxidation of the Si surface, which is controlled only by the position of $\mathbf{E}_{\mathrm{F}, \mathrm{p}}$ for interfaces controlled by an applied external bias. Consistently, the potentiostatic methoxylation of p-type interfaces exhibited no dependence on the illumination conditions during the reaction.

IV.F. Relevance to other Reactions at H-Si(111) Surfaces. In the presence of alkyl halide impurities, the reaction of Grignard reagents with $\mathrm{H}-\mathrm{Si}(111)$ surfaces proceeds more rapidly at n-type surfaces than p-type surfaces. ${ }^{77}$ Additionally, anodic electrografting of alkynes on porous $\mathrm{H}-\mathrm{Si}(111)$ surfaces results in the attachment of fully saturated hydrocarbons to the $\mathrm{H}-$ $\operatorname{Si}(111)$ surface $^{5}$ by a pathway that is similar to the potentiostatic methoxylation reaction discussed herein. The rate of hydrosilylation at $\mathrm{H}-\mathrm{Si}(111)$ surfaces is sensitive to the energy levels of electron acceptors in solution. ${ }^{4}$ Moreover, hydrosilylation reactions of molecular silanes typically require ultraviolet illumination, whereas $\mathrm{H}-\mathrm{Si}(111)$ surfaces react with unsaturated hydrocarbons under visible-light illumination ${ }^{51}$ as well as under certain circumstances in the dark at room temperature. ${ }^{50,78}$

The mechanisms for the reactions of Grignard reagents, alkenes, and alkynes at $\mathrm{H}-\mathrm{Si}(111)$ surfaces involve electron transfer kinetics that closely parallel the reaction of $\mathrm{CH}_{3} \mathrm{OH}$ with $\mathrm{H}-$ $\operatorname{Si}(111)$ surfaces. These reactions are known to be sensitive to the bulk electronic structure of the $\mathrm{Si}^{77,79}$ in ways that are consistent with the behavior of the oxidant-activated methoxylation reaction. The kinetic formalism and mechanistic framework developed herein for oxidantactivated reactivity of $\mathrm{H}-\mathrm{Si}(111)$ surfaces could therefore potentially provide insights into a wide range of apparently disparate reactions that occur at $\mathrm{H}-\mathrm{Si}(111)$ surfaces but do not readily proceed with molecular silane small-molecule analogs of the H-terminated Si(111) surface. 


\section{CONCLUSIONS}

The reaction of $\mathrm{H}-\mathrm{Si}(111)$ surfaces with $\mathrm{CH}_{3} \mathrm{OH}$ was investigated in the absence or presence of a molecular oxidant and in the absence or presence of illumination. The oxidantactivated methoxylation of $\mathrm{H}-\mathrm{Si}(111)$ surfaces in the dark proceeded in the presence of oxidants that provided a solution energy, $\mathbf{E}\left(\mathrm{A} / \mathrm{A}^{-}\right)$, in proximity to or negative of the valence-band maximum, $\mathbf{E}_{\mathrm{vb}}$. Under ambient illumination, the oxidant-activated methoxylation of intrinsic and n-type $\mathrm{H}-\mathrm{Si}(111)$ surfaces exhibited increased reactivity and allowed for oxidants that did not perform oxidant-activated methoxylation in the dark to impart an increased rate of methoxylation in the light. A mechanistic framework that analyzes the positions of the quasi-Fermi levels indicates that conditions that favor oxidation of the $\mathrm{H}-\mathrm{Si}(111)$ surface, while also favoring reduction of oxidants in solution, must be met for oxidant-activated methoxylation to readily proceed. Potentiostatic methoxylation in the dark revealed that the oxidation potential of the $\mathrm{Si}$ surface, $\mathbf{E}\left(\mathrm{Si}^{+/ 0}\right)$, was $\sim 0 \mathrm{~V}$ vs SCE, falling near the middle of the Si band gap. Illumination of $\mathrm{n}$ type $\mathrm{H}-\mathrm{Si}(111)$ surfaces exposed to $\mathrm{CH}_{3} \mathrm{OH}$ under an applied external bias resulted in an increase in the anodic current density and a negative shift in $E_{1 / 2}$, whereas p-type H-Si(111) surfaces exposed to $\mathrm{CH}_{3} \mathrm{OH}$ under applied external bias were unaffected by the presence of illumination.

The unique reactivity of $\mathrm{H}-\mathrm{Si}(111)$ surfaces toward $\mathrm{CH}_{3} \mathrm{OH}$, not observed for small molecule silanes, appears to arise from the narrow band gap of crystalline Si and the capacity of the crystal lattice to form an electric field at the interface that can favor charge transfer in the desired direction. Molecular systems do not have the necessary density of electronic states to facilitate the oxidant-activated methoxylation reaction, for the oxidants used herein. The results and kinetic formalism developed herein thus provide a basis to understand the processes by 
which nucleophiles, including alcohols, alkenes, alkynes, and Grignards, can undergo reaction with $\mathrm{H}-\mathrm{Si}(111)$ surfaces in the presence or absence of an oxidant and/or an illumination source.

\section{ASSOCIATED CONTENT}

\section{Supporting Information}

The supporting information is available free of charge on the ACS publications website at DOI:

Supporting Figures S1-S5, a discussion of the observation of F by XPS on methoxylated $\mathrm{H}-\mathrm{Si}(111)$ surfaces, and a derivation of eqs $8-11$ in the main text.

\section{AUTHOR INFORMATION}

\section{Corresponding Author}

*(N.S.L.) E-mail: nslewis@caltech.edu. Tel: (626) 395-6335.

\section{Notes}

The authors declare no competing financial interest.

\section{ACKNOWLEDGEMENTS}

We acknowledge the National Science Foundation grant No. CHE-1214152 for providing support for the materials used in this work. Instrumentation support was provided by the Molecular Materials Research Center of the Beckman Institute at the California Institute of Technology. N.T.P. acknowledges support from a National Science Foundation Graduate Research Fellowship. M.D. acknowledges support from a postdoctoral fellowship from the National Sciences and Engineering Research Council of Canada. N.T.P. and B.S.B acknowledge support from the National Science Foundation CCI Solar Fuels Program under Grant No. CHE1305124. We thank Dr. Adam C. Nielander for insightful discussions during the preparation of this work. 


\section{REFERENCES}

1. Peng, W.; Rupich, S. M.; Shafiq, N.; Gartstein, Y. N.; Malko, A. V.; Chabal, Y. J. Silicon Surface Modification and Characterization for Emergent Photovoltaic Applications Based on Energy Transfer. Chem. Rev. 2015, 115, 12764-12796.

2. Smith, W. A.; Sharp, I. D.; Strandwitz, N. C.; Bisquert, J. Interfacial Band-Edge Energetics for Solar Fuels Production. Energy Environ. Sci. 2015, 8, 2851-2862.

3. Buriak, J. M. Illuminating Silicon Surface Hydrosilylation: An Unexpected Plurality of Mechanisms. Chem. Mater. 2014, 26, 763-772.

4. Huck, L. A.; Buriak, J. M. UV-Initiated Hydrosilylation on Hydrogen-Terminated Silicon (111): Rate Coefficient Increase of Two Orders of Magnitude in the Presence of Aromatic Electron Acceptors. Langmuir 2012, 28, 16285-16293.

5. Robins, E. G.; Stewart, M. P.; Buriak, J. M. Anodic and Cathodic Electrografting of Alkynes on Porous Silicon. Chem. Commun. 1999, 2479-2480.

6. Ciampi, S.; Böcking, T.; Kilian, K. A.; James, M.; Harper, J. B.; Gooding, J. J. Functionalization of Acetylene-Terminated Monolayers on Si(100) Surfaces: A Click Chemistry Approach. Langmuir 2007, 23, 9320-9329.

7. Dai, M.; Wang, Y.; Kwon, J.; Halls, M. D.; Chabal, Y. J. Nitrogen Interaction with Hydrogen-Terminated Silicon Surfaces at the Atomic Scale. Nat. Mater. 2009, 8, 825-830.

8. Tian, F.; Teplyakov, A. V. Silicon Surface Functionalization Targeting Si-N Linkages. Langmuir 2013, 29, 13-28.

9. Tian, F.; Taber, D. F.; Teplyakov, A. V. -NH- Termination of the Si(111) Surface by Wet Chemistry. J. Am. Chem. Soc. 2011, 133, 20769-20777. 
10. Chopra, T. P.; Longo, R. C.; Cho, K.; Chabal, Y. J. Ammonia Modification of Oxide-Free Si(111) Surfaces. Surf. Sci. 2016, 650, 285-294.

11. Chopra, T. P.; Longo, R. C.; Cho, K.; Halls, M. D.; Thissen, P.; Chabal, Y. J. Ethylenediamine Grafting on Oxide-Free H-, 1/3 ML F-, and Cl-Terminated Si(111) Surfaces. Chem. Mater. 2015, 27, 6268-6281.

12. Buriak, J. M.; Sikder, M. D. H. From Molecules to Surfaces: Radical-Based Mechanisms of Si-S and Si-Se Bond Formation on Silicon. J. Am. Chem. Soc. 2015, 137, 9730-9738.

13. Hu, M.; Liu, F.; Buriak, J. M. Expanding the Repertoire of Molecular Linkages to Silicon: Si-S, Si-Se, and Si-Te Bonds. ACS Appl. Mater. Inter. 2016, 8, 11091-11099.

14. Yamada, T.; Shirasaka, K.; Noto, M.; Kato, H. S.; Kawai, M. Adsorption of Unsaturated Hydrocarbon Moieties on H:Si(111) by Grignard Reaction. J. Phys. Chem. B 2006, 110, $7357-7366$.

15. Boukherroub, R.; Morin, S.; Bensebaa, F.; Wayner, D. D. M. New Synthetic Routes to Alkyl Monolayers on the Si(111) Surface. Langmuir 1999, 15, 3831-3835.

16. Cleland, G.; Horrocks, B. R.; Houlton, A. Direct Functionalization of Silicon via the SelfAssembly of Alcohols. J. Chem. Soc., Faraday Trans. 1995, 91, 4001-4003.

17. Haber, J. A.; Lauermann, I.; Michalak, D.; Vaid, T. P.; Lewis, N. S. Electrochemical and Electrical Behavior of (111)-Oriented Si Surfaces Alkoxylated through Oxidative Activation of Si-H Bonds. J. Phys. Chem. B 2000, 104, 9947-9950.

18. Haber, J. A.; Lewis, N. S. Infrared and X-ray Photoelectron Spectroscopic Studies of the Reactions of Hydrogen-Terminated Crystalline $\mathrm{Si}(111)$ and $\mathrm{Si}(100)$ Surfaces with $\mathrm{Br}_{2}, \mathrm{I}_{2}$, and Ferrocenium in Alcohol Solvents. J. Phys. Chem. B 2002, 106, 3639-3656. 
19. Michalak, D. J.; Amy, S. R.; Aureau, D.; Dai, M.; Esteve, A.; Chabal, Y. J. Nanopatterning Si(111) Surfaces as a Selective Surface-Chemistry Route. Nat. Mater. 2010, 9, 266-271.

20. Michalak, D. J.; Amy, S. R.; Estève, A.; Chabal, Y. J. Investigation of the Chemical Purity of Silicon Surfaces Reacted with Liquid Methanol. J. Phys. Chem. C 2008, 112, $11907-$ 11919.

21. Michalak, D. J.; Rivillon, S.; Chabal, Y. J.; Estève, A.; Lewis, N. S. Infrared Spectroscopic Investigation of the Reaction of Hydrogen-Terminated, (111)-Oriented, Silicon Surfaces with Liquid Methanol. J. Phys. Chem. B 2006, 110, 20426-20434.

22. Dusciac, D.; Chazalviel, J.-N.; Ozanam, F.; Allongue, P.; de Villeneuve, C. H. Thermal Stability of Alkoxy Monolayers Grafted on Si(111). Surf. Sci. 2007, 601, 3961-3964.

23. Boukherroub, R.; Morin, S.; Sharpe, P.; Wayner, D. D. M.; Allongue, P. Insights into the Formation Mechanisms of $\mathrm{Si}-\mathrm{OR}$ Monolayers from the Thermal Reactions of Alcohols and Aldehydes with Si(111)-H. Langmuir 2000, 16, 7429-7434.

24. Thissen, P.; Fuchs, E.; Roodenko, K.; Peixoto, T.; Batchelor, B.; Smith, D.; Schmidt, W. G.; Chabal, Y. Nanopatterning on H-Terminated Si(111) Explained as Dynamic Equilibrium of the Chemical Reaction with Methanol. J. Phys. Chem. C 2015, 119, 16947-16953.

25. Khung, Y. L.; Ngalim, S. H.; Meda, L.; Narducci, D. Preferential Formation of Si-O-C over Si-C Linkage upon Thermal Grafting on Hydrogen-Terminated Silicon (111). Chem. Eur. J. 2014, 20, 15151-15158.

26. Perrine, K. A.; Lin, J.-M.; Teplyakov, A. V. Controlling the Formation of Metallic Nanoparticles on Functionalized Silicon Surfaces. J. Phys. Chem. C 2012, 116, 1443114444. 
27. Aureau, D.; Varin, Y.; Roodenko, K.; Seitz, O.; Pluchery, O.; Chabal, Y. J. Controlled Deposition of Gold Nanoparticles on Well-Defined Organic Monolayer Grafted on Silicon Surfaces. J. Phys. Chem. C 2010, 114, 14180-14186.

28. Maldonado, S.; Knapp, D.; Lewis, N. S. Near-Ideal Photodiodes from Sintered Gold Nanoparticle Films on Methyl-Terminated Si(111) Surfaces. J. Am. Chem. Soc. 2008, 130, $3300-3301$.

29. Nguyen, H. M.; Seitz, O.; Aureau, D.; Sra, A.; Nijem, N.; Gartstein, Y. N.; Chabal, Y. J.; Malko, A. V. Spectroscopic Evidence for Nonradiative Energy Transfer between Colloidal CdSe/ZnS Nanocrystals and Functionalized Silicon Substrates. Appl. Phys. Lett. 2011, 98, 161904.

30. Khatri, O. P.; Ichii, T.; Murase, K.; Sugimura, H. UV Induced Covalent Assembly of Gold Nanoparticles in Linear Patterns on Oxide Free Silicon Surface. J. Mater. Chem. 2012, 22, 16546-16551.

31. Caillard, L.; Seitz, O.; Campbell, P. M.; Doherty, R. P.; Lamic-Humblot, A.-F.; Lacaze, E.; Chabal, Y. J.; Pluchery, O. Gold Nanoparticles on Oxide-Free Silicon-Molecule Interface for Single Electron Transport. Langmuir 2013, 29, 5066-5073.

32. O’Leary, L. E.; Strandwitz, N. C.; Roske, C. W.; Pyo, S.; Brunschwig, B. S.; Lewis, N. S. Use of Mixed $\mathrm{CH}_{3}-\mathrm{HC}(\mathrm{O}) \mathrm{CH}_{2} \mathrm{CH}_{2}-\mathrm{Si}(111)$ Functionality to Control Interfacial Chemical and Electronic Properties During the Atomic-Layer Deposition of Ultrathin Oxides on Si(111). J. Phys. Chem. Lett. 2015, 6, 722-726.

33. Li, M.; Dai, M.; Chabal, Y. J. Atomic Layer Deposition of Aluminum Oxide on Carboxylic Acid-Terminated Self-Assembled Monolayers. Langmuir 2009, 25, 1911-1914. 
34. Peng, W.; Seitz, O.; Chapman, R. A.; Vogel, E. M.; Chabal, Y. J. Probing the Intrinsic Electrical Properties of Thin Organic Layers/Semiconductor Interfaces using an AtomicLayer-Deposited $\mathrm{Al}_{2} \mathrm{O}_{3}$ Protective Layer. Appl. Phys. Lett. 2012, 101, 051605.

35. Peng, W.; DeBenedetti, W. J. I.; Kim, S.; Hines, M. A.; Chabal, Y. J. Lowering the Density of Electronic Defects on Organic-Functionalized Si(100) Surfaces. Appl. Phys. Lett. 2014, 104,241601

36. Bruce, J. P.; Oliver, D. R.; Lewis, N. S.; Freund, M. S. Electrical Characteristics of the Junction between PEDOT:PSS and Thiophene-Functionalized Silicon Microwires. ACS Appl. Mater. Inter. 2015, 7, 27160-27166.

37. Giesbrecht, P. K.; Bruce, J. P.; Freund, M. S. Electric and Photoelectric Properties of 3,4Ethylenedioxythiophene-Functionalized n-Si/PEDOT:PSS Junctions. ChemSusChem 2016, 9, 109-117.

38. Sailor, M. J.; Klavetter, F. L.; Grubbs, R. H.; Lewis, N. S. Electronic Properties of Junctions between Silicon and Organic Conducting Polymers. Nature 1990, 346, 155-157.

39. Gallant, B. M.; Gu, X. W.; Chen, D. Z.; Greer, J. R.; Lewis, N. S. Tailoring of Interfacial Mechanical Shear Strength by Surface Chemical Modification of Silicon Microwires Embedded in Nafion Membranes. ACS Nano 2015, 9, 5143-5153.

40. Zhang, F.; Liu, D.; Zhang, Y.; Wei, H.; Song, T.; Sun, B. Methyl/Allyl Monolayer on Silicon: Efficient Surface Passivation for Silicon-Conjugated Polymer Hybrid Solar Cell. ACS Appl. Mater. Inter. 2013, 5, 4678-4684.

41. Cho, C. J.; O’Leary, L.; Lewis, N. S.; Greer, J. R. In Situ Nanomechanical Measurements of Interfacial Strength in Membrane-Embedded Chemically Functionalized Si Microwires for Flexible Solar Cells. Nano Lett. 2012, 12, 3296-3301. 
42. Fabre, B. Functionalization of Oxide-Free Silicon Surfaces with Redox-Active Assemblies. Chem. Rev. 2016, 116, 4808-4849.

43. Lattimer, J. R. C.; Blakemore, J. D.; Sattler, W.; Gul, S.; Chatterjee, R.; Yachandra, V. K.; Yano, J.; Brunschwig, B. S.; Lewis, N. S.; Gray, H. B. Assembly, Characterization, and Electrochemical Properties of Immobilized Metal Bipyridyl Complexes on Silicon(111) Surfaces. Dalton Trans. 2014, 43, 15004-15012.

44. Lattimer, J. R. C.; Brunschwig, B. S.; Lewis, N. S.; Gray, H. B. Redox Properties of Mixed Methyl/Vinylferrocenyl Monolayers on Si(111) Surfaces. J. Phys. Chem. C 2013, 117, $27012-27022$.

45. Kang, O. S.; Bruce, J. P.; Herbert, D. E.; Freund, M. S. Covalent Attachment of Ferrocene to Silicon Microwire Arrays. ACS Appl. Mater. Inter. 2015, 7, 26959-26967.

46. O’Leary, L. E.; Rose, M. J.; Ding, T. X.; Johansson, E.; Brunschwig, B. S.; Lewis, N. S. Heck Coupling of Olefins to Mixed Methyl/Thienyl Monolayers on Si(111) Surfaces. J. Am. Chem. Soc. 2013, 135, 10081-10090.

47. Yzambart, G.; Fabre, B.; Roisnel, T.; Dorcet, V.; Ababou-Girard, S.; Meriadec, C.; Lorcy, D. Assembly of Platinum Diimine Dithiolate Complexes onto Hydrogen-Terminated Silicon Surfaces. Organometallics 2014, 33, 4766-4776.

48. Seo, J.; Pekarek, R. T.; Rose, M. J. Photoelectrochemical Operation of a Surface-Bound, Nickel-Phosphine $\mathrm{H}_{2}$ Evolution Catalyst on p-Si(111): A Molecular Semiconductor|Catalyst Construct. Chem. Commun. 2015, 51, 13264-13267.

49. Fabre, B.; Cordier, S.; Molard, Y.; Perrin, C.; Ababou-Girard, S.; Godet, C. Electrochemical and Charge Transport Behavior of Molybdenum-Based Metallic Cluster 
Layers Immobilized on Modified n- and p-Type Si(111) Surfaces. J. Phys. Chem. C 2009, $113,17437-17446$.

50. Ciampi, S.; Luais, E.; James, M.; Choudhury, M. H.; Darwish, N. A.; Gooding, J. J. The Rapid Formation of Functional Monolayers on Silicon under Mild Conditions. Phys. Chem. Chem. Phys. 2014, 16, 8003-8011.

51. Sun, Q.-Y.; de Smet, L. C. P. M.; van Lagen, B.; Giesbers, M.; Thüne, P. C.; van Engelenburg, J.; de Wolf, F. A.; Zuilhof, H.; Sudhölter, E. J. R. Covalently Attached Monolayers on Crystalline Hydrogen-Terminated Silicon: Extremely Mild Attachment by Visible Light. J. Am. Chem. Soc. 2005, 127, 2514-2523.

52. Wayner, D. D. M.; Wolkow, R. A. Organic Modification of Hydrogen Terminated Silicon Surfaces. J. Chem. Soc., Perkin Trans. 2 2002, 23-34.

53. Rosenbluth, M. L.; Lieber, C. M.; Lewis, N. S. 630-mV Open Circuit Voltage, 12\% Efficient n-Si Liquid Junction. Appl. Phys. Lett. 1984, 45, 423-425.

54. Gibbons, J. F.; Cogan, G. W.; Gronet, C. M.; Lewis, N. S. A 14\% efficient nonaqueous semiconductor/liquid junction solar cell. Appl. Phys. Lett. 1984, 45, 1095-1097.

55. Michalak, D. J.; Lewis, N. S. Use of Near-Surface Channel Conductance and Differential Capacitance versus Potential Measurements to Correlate Inversion Layer Formation with Low Effective Surface Recombination Velocities at n-Si/Liquid Contacts. Appl. Phys. Lett. 2002, $80,4458-4460$.

56. Gstrein, F.; Michalak, D. J.; Royea, W. J.; Lewis, N. S. Effects of Interfacial Energetics on the Effective Surface Recombination Velocity of Si/Liquid Contacts. J. Phys. Chem. B $\mathbf{2 0 0 2}, 106,2950-2961$. 
57. Royea, W. J.; Michalak, D. J.; Lewis, N. S. Role of Inversion Layer Formation in Producing Low Effective Surface Recombination Velocities at Si/lLiquid Contacts. Appl. Phys. Lett. 2000, 77, 2566-2568.

58. Chazalviel, J. N. Surface Methoxylation as the Key Factor for the Good Performance of nSi/Methanol Photoelectrochemical Cells. J. Electroanal. Chem. Interfacial Electrochem. 1987, 233, 37-48.

59. Rijksen, B.; van Lagen, B.; Zuilhof, H. Mimicking the Silicon Surface: Reactivity of Silyl Radical Cations toward Nucleophiles. J. Am. Chem. Soc. 2011, 133, 4998-5008.

60. Giese, B.; Dickhaut, J.; Chatgilialoglu, C., Tris(trimethylsilyl)silane. In Encyclopedia of Reagents for Organic Synthesis, John Wiley \& Sons, Ltd: 2001.

61. Kim, N. Y.; Laibinis, P. E. Thermal Derivatization of Porous Silicon with Alcohols. J. Am. Chem. Soc. 1997, 119, 2297-2298.

62. Skibinski, E. S.; DeBenedetti, W. J. I.; Rupich, S. M.; Chabal, Y. J.; Hines, M. A. Frustrated Etching during H/Si(111) Methoxylation Produces Fissured Fluorinated Surfaces, Whereas Direct Fluorination Preserves the Atomically Flat Morphology. J. Phys. Chem. C 2015, 119, 26029-26037.

63. Sze, S. M.; Ng, K. K., Physics of Semiconductor Devices; John Wiley \& Sons, Inc., 2007.

64. Hunger, R.; Fritsche, R.; Jaeckel, B.; Jaegermann, W.; Webb, L. J.; Lewis, N. S. Chemical and Electronic Characterization of Methyl-Terminated $\operatorname{Si}(111)$ Surfaces by HighResolution Synchrotron Photoelectron Spectroscopy. Phys. Rev. B 2005, 72, 045317.

65. Hendrickson, D. N.; Sohn, Y. S.; Gray, H. B. Magnetic Susceptibility Study of Various Ferricenium and Iron(III) Dicarbollide Compounds. Inorg. Chem. 1971, 10, 1559-1563. 
66. Grimm, R. L.; Bierman, M. J.; O’Leary, L. E.; Strandwitz, N. C.; Brunschwig, B. S.; Lewis, N. S. Comparison of the Photoelectrochemical Behavior of H-Terminated and MethylTerminated $\operatorname{Si}(111)$ Surfaces in Contact with a Series of One-Electron, Outer-Sphere Redox Couples in $\mathrm{CH}_{3}$ CN. J. Phys. Chem. C 2012, 116, 23569-23576.

67. Plymale, N. T.; Kim, Y.-G.; Soriaga, M. P.; Brunschwig, B. S.; Lewis, N. S. Synthesis, Characterization, and Reactivity of Ethynyl- and Propynyl-Terminated Si(111) Surfaces. J. Phys. Chem. C 2015, 119, 19847-19862.

68. Plymale, N. T.; Ramachandran, A. A.; Lim, A.; Brunschwig, B. S.; Lewis, N. S. Control of the Band-Edge Positions of Crystalline $\mathrm{Si}(111)$ by Surface Functionalization with 3,4,5Trifluorophenylacetylenyl Moieties. J. Phys. Chem. C 2016, 120, 14157-14169.

69. Dekker, M., Standard Potentials in Aqueous Solution; CRC Press, Inc.: New York, 1985.

70. Trasatti, S. The Absolute Electrode Potential: An Explanatory Note. Pure Appl. Chem. 1986, 58, 955-966.

71. Pavlishchuk, V. V.; Addison, A. W. Conversion Constants for Redox Potentials Measured versus Different Reference Electrodes in Acetonitrile Solutions at $25^{\circ} \mathrm{C}$. Inorg. Chim. Acta 2000, 298, 97-102.

72. Pomykal, K. E.; Fajardo, A. M.; Lewis, N. S. Stability of n-Si/CH Function of the Reorganization Energy of the Electron Donor. J. Phys. Chem. 1995, 99, $8302-8310$

73. Shreve, G. A.; Karp, C. D.; Pomykal, K. E.; Lewis, N. S. Limits on the Corrosion Rate of Si Surfaces in Contact with $\mathrm{CH}_{3} \mathrm{OH}-\mathrm{Ferrocene}{ }^{+/ 0}$ and $\mathrm{CH}_{3} \mathrm{OH}-1,1^{\prime}-$ Dimethylferrocene ${ }^{+/ 0}$ Solutions. J. Phys. Chem. 1995, 99, 5575-5580. 
74. Nakamura, T.; Miyajima, K.; Hirata, N.; Matsumoto, T.; Morikawa, Y.; Tada, H.; Nakajima, A. Electronic Structure of Hydrogen-Terminated Silicon Surfaces [H-Si(111)] Studied by Two-Photon Photoemission. Appl. Phys. A 2010, 98, 735-743.

75. Blase, X.; Zhu, X.; Louie, S. G. Self-Energy Effects on the Surface-State Energies of HSi(111)1x1. Phys. Rev. B 1994, 49, 4973-4980.

76. Li, Y.; Galli, G. Electronic and Spectroscopic Properties of the Hydrogen-Terminated Si(111) Surface from ab initio Calculations. Phys. Rev. B 2010, 82, 045321.

77. Fellah, S.; Boukherroub, R.; Ozanam, F.; Chazalviel, J.-N. Hidden Electrochemistry in the Thermal Grafting of Silicon Surfaces from Grignard Reagents. Langmuir 2004, 20, 63596364.

78. Scheres, L.; Giesbers, M.; Zuilhof, H. Self-Assembly of Organic Monolayers onto Hydrogen-Terminated Silicon: 1-Alkynes Are Better Than 1-Alkenes. Langmuir 2010, 26, 10924-10929.

79. Langner, A.; Panarello, A.; Rivillon, S.; Vassylyev, O.; Khinast, J. G.; Chabal, Y. J. Controlled Silicon Surface Functionalization by Alkene Hydrosilylation. J. Am. Chem. Soc. 2005, 127, 12798-12799. 


\section{TOC Graphic}

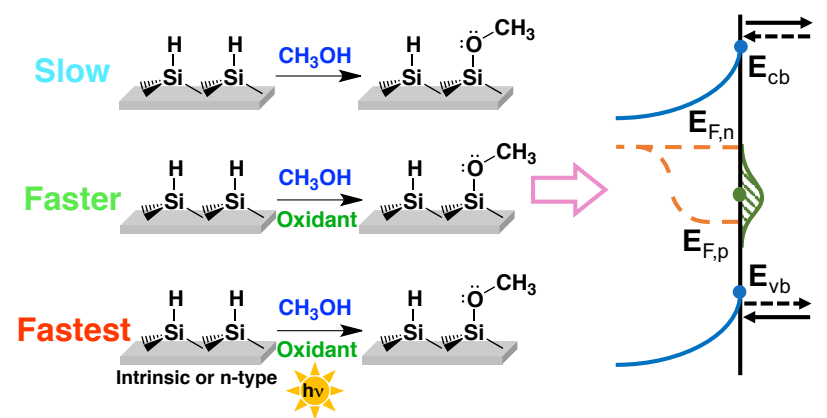

15

17

18

19

20

21

22

23

24

25

26

27

28

29

30

31

32

33

34

35

36

37

38

39

40

41

42

43

44

45

46

47

48

49

50

51

52

53

54

55

56

57

58

59

60 